تأثير اقليم و تكامل خاك بر مقدار و توزيع شكلهاى شيميايى عناصر غذايى كممصرف آهن، مس، روى و منگنز در سرىهاى غالب خاكهاى استان كهيلويه و بويراحمد

\author{
سيروس شاكرى'"، ابوالفضل آزادى و محبوب صفارى" \\ (تاريخ دريافت:
}

جكيده

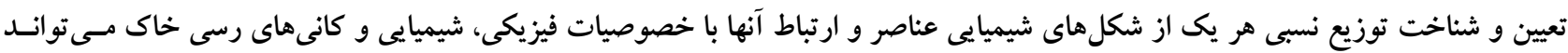

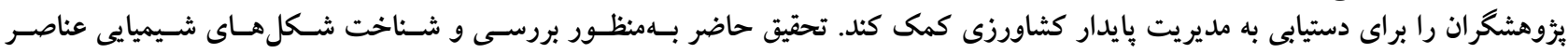

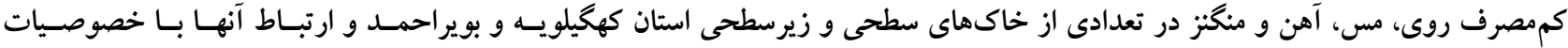

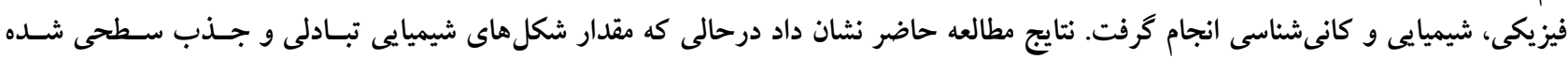

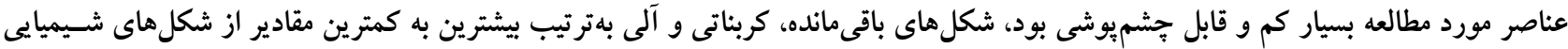

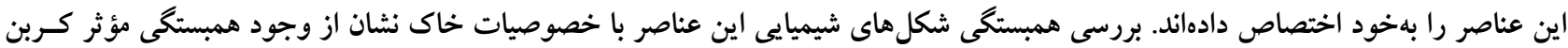

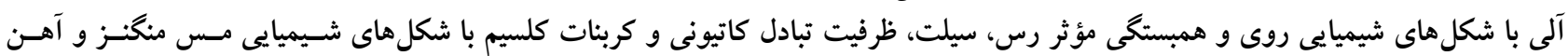

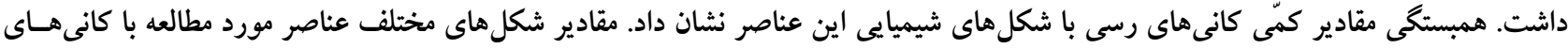

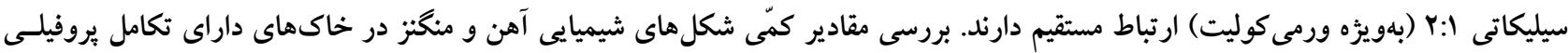

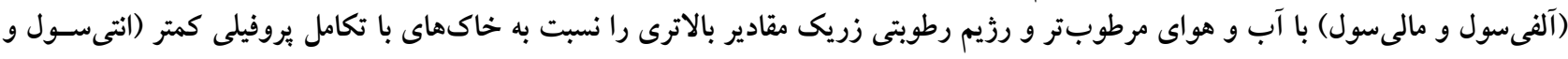

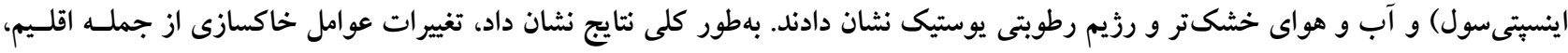

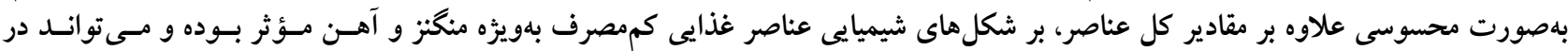

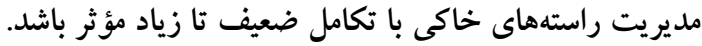

وازههاى كليدى: شكلهاى شيميايى، عناصر غذايى كممصرف، كانىهاى رسى

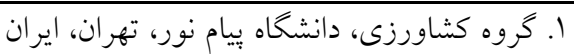

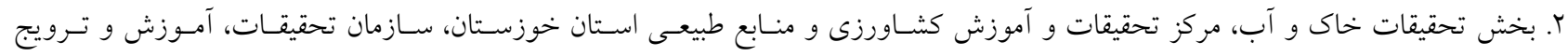
كثاورزى، اهواز، ايران

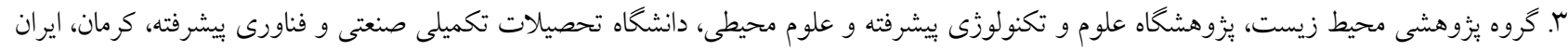

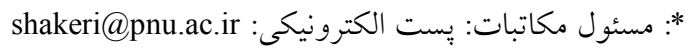


نامناسب اسمكتايت بيشترى مشاهده مىشود.

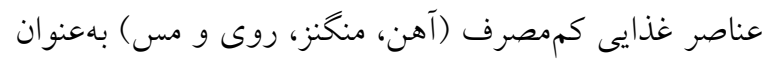

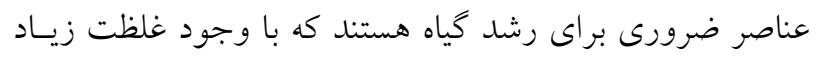

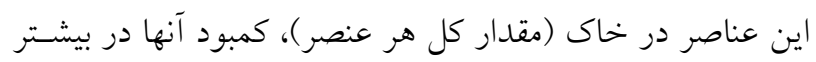

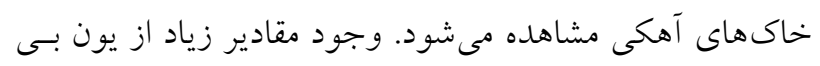
كربنات در محلول خاى، عدم تهويه مناسب خاك، بِهاش باش بالا،

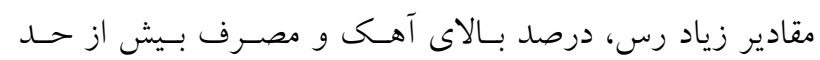
كودهــاى فسـفرى بـهـعــوان عوامـل اصـلى در كـاهش قابليـت

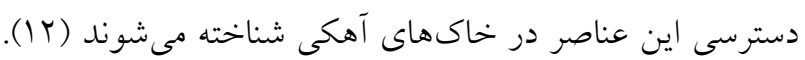
ميزان قابليت دسترسى عناصر كممصرف در خـاك، نـه تنهـا بـهـ

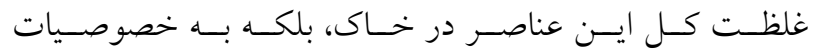

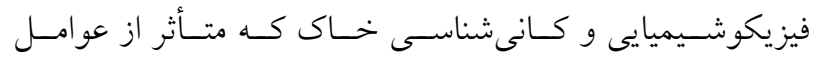
خاكسازى و نوع خاك مبتنى بر نوع رزيمهاى رطوبتى، حرارتى ونى

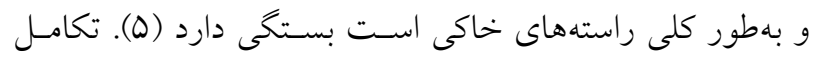
خاك، شرايط فيزيو گرافيك و رزيمهاى حرارتى و رطوبتى خاى

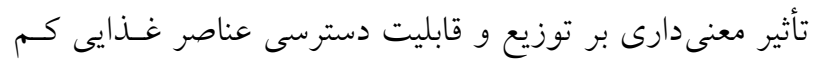

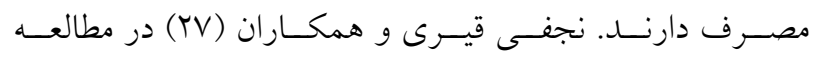

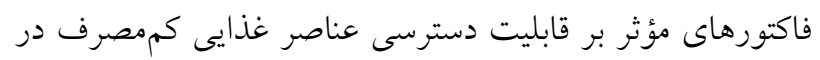

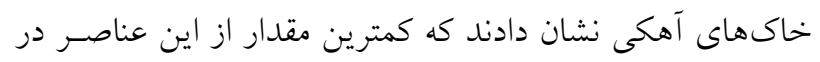

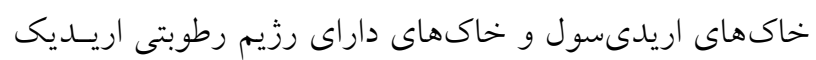

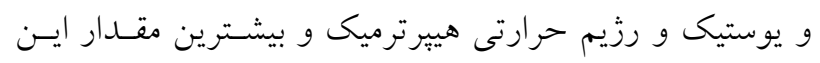

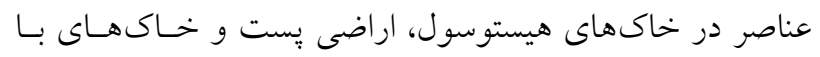

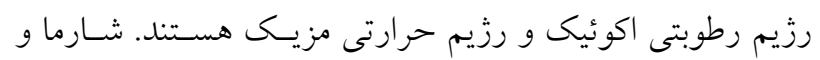

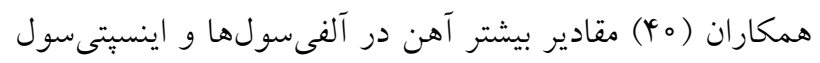

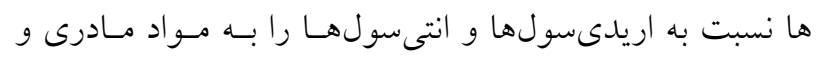

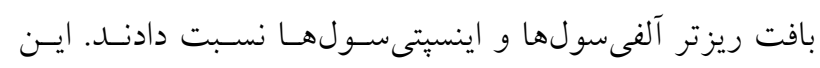

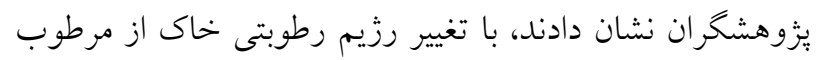

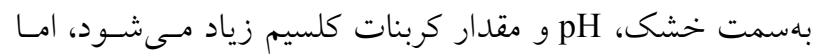

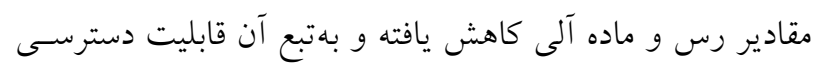

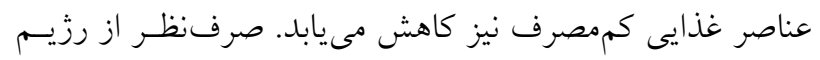

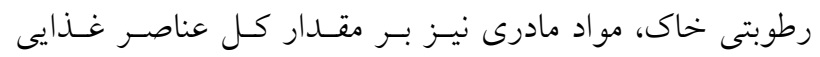

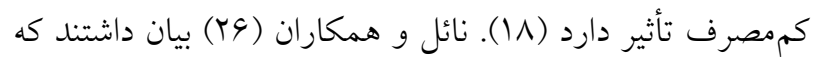

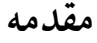

شرايط زئويدولوزيك حاكم بر محيط خاك، عامل اصلى مــؤثر

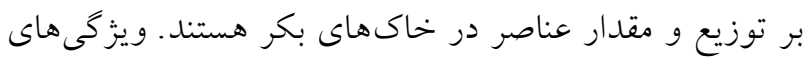
مختلف خاك اعم از pH ، مقدار رس، ميزان تخلخل، كربنـات

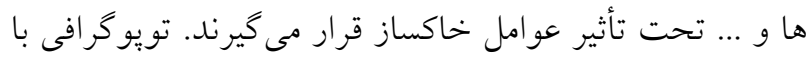
تغيير الكوى بارش و دما، اقليمهاى محلى را تحت تأثير قـرار

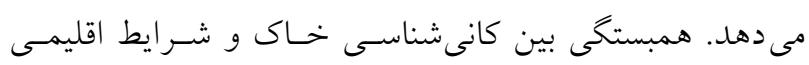

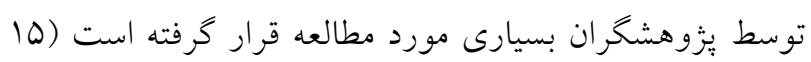

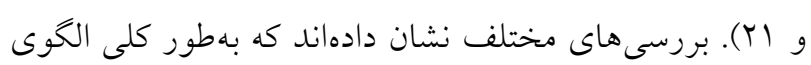

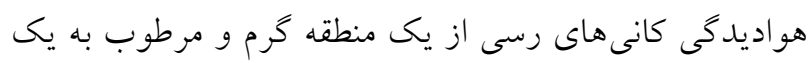

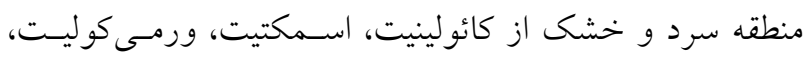
كلريت و فيلوسيليكاتهاى مختلط به كانى هاى ايليت و ميكـا

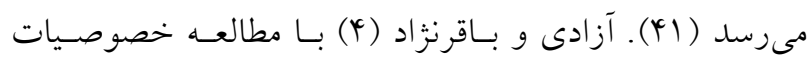
خاك و كانىشناسى سه منطقـهـ اسـتان فـارس بــه ايـن نتيجـهـ رسيدند كه شاخص اقليمى با توجسه بـه نقشى كـه در تعيسين

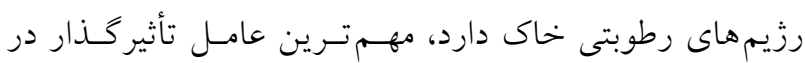

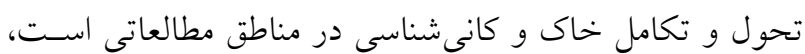

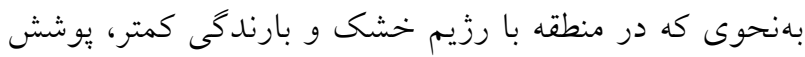

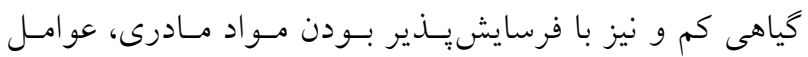

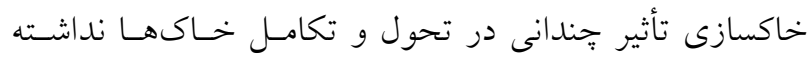

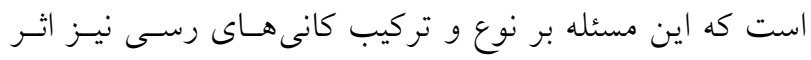

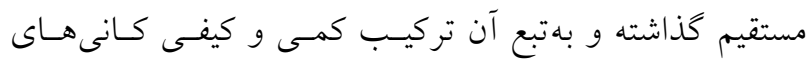

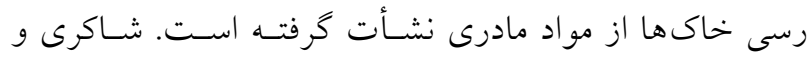

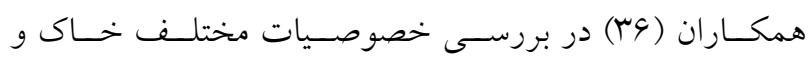

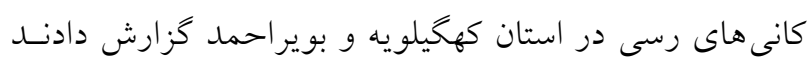

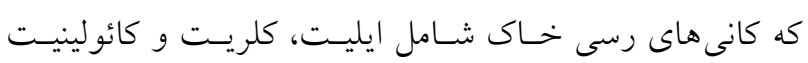

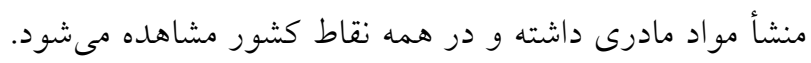

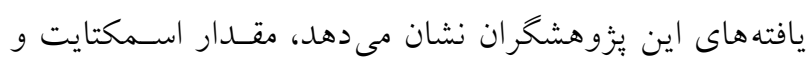

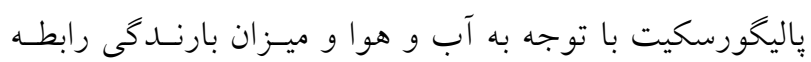

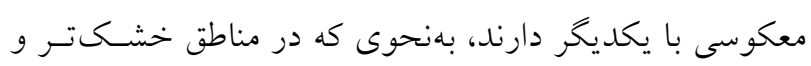

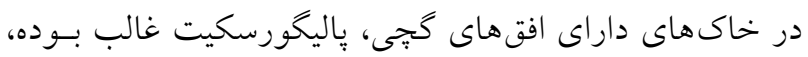

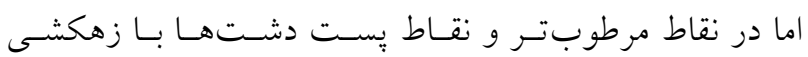




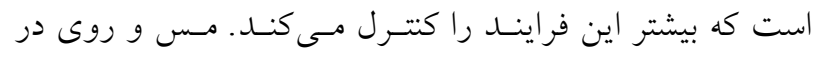

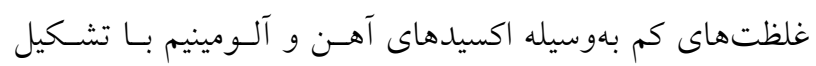

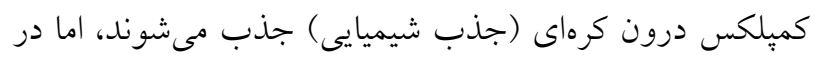

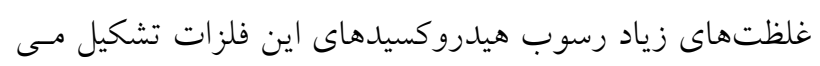

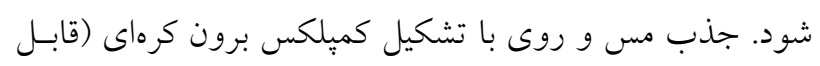

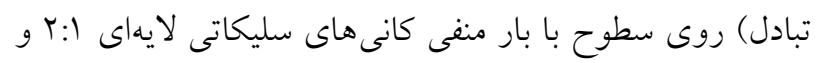

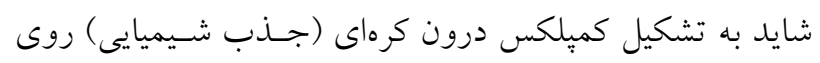

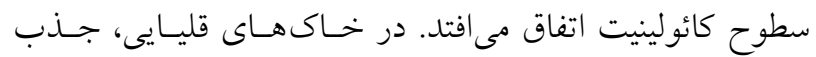
روى روى كلسيت و همرسوبى مس در كلسيت اتفاق مسىافتـد

معمولاً در مطالعات تفصيلى شناسايى خاك، خاكهاى روى واحدهاى زمين نما به سرىهاى كم و بيش طبيعى تقسيم مسى

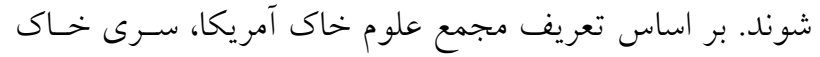

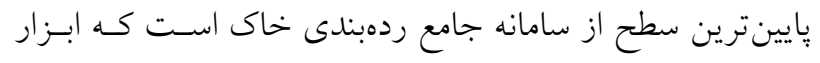

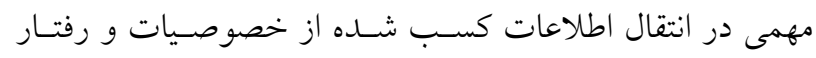
يكى خاى براى خاكهاى مشابه در مناطق ديخر است. بـا توجـهـ

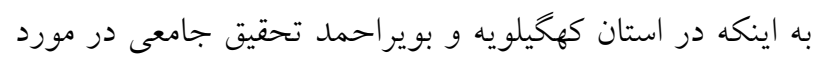

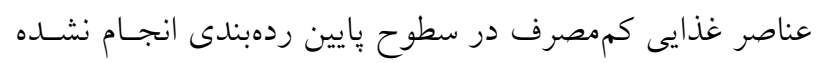

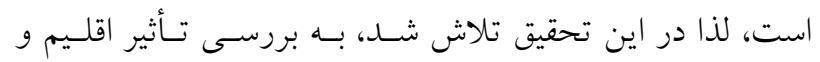

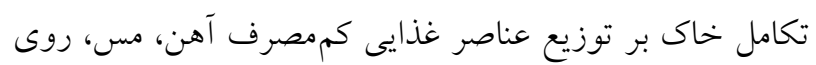

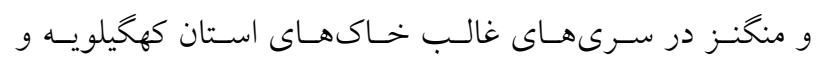
بوير احمد برداخته شود.

\section{مواد و روشها}

\section{تشريح موقعيت منطقه}

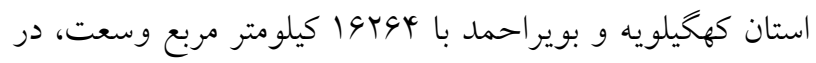
جنوب غربى ايران، در محدوده مب درجه و 9 دقيقه تا اسب درجه

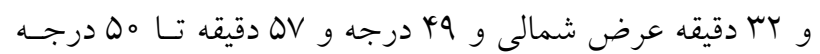

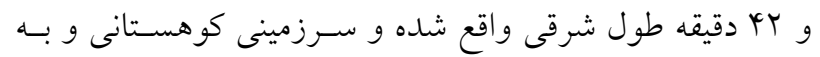

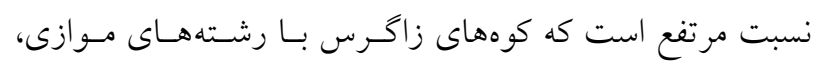
سراسر شمال و شرق آن را دربر كرفتهاند. بلندترين نقطه استان،

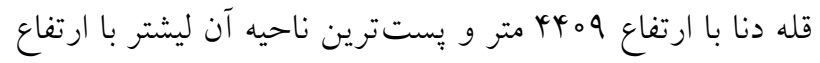

مـو اد مـادرى و همجنــين فراينـدهاى خاكسـازى روى ميـزان و

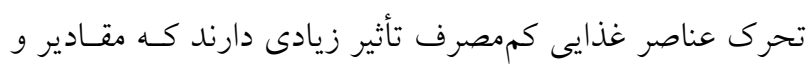

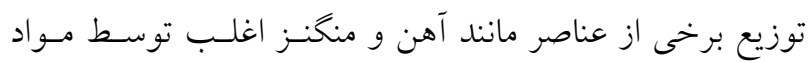

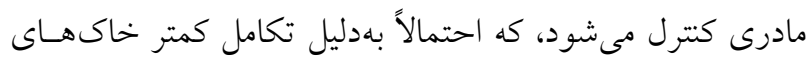

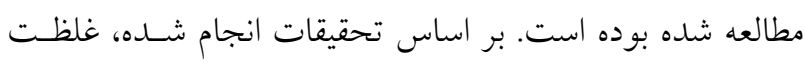

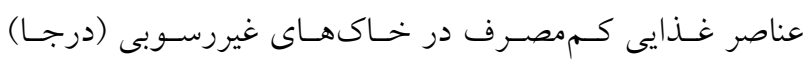
بستكى به نوع سنخ بستر كه مـواد مـادرى خــاك از آن مشـتق

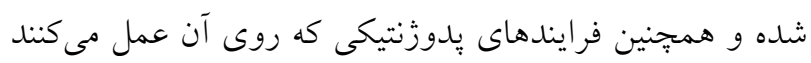

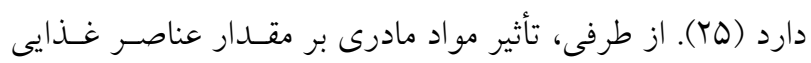

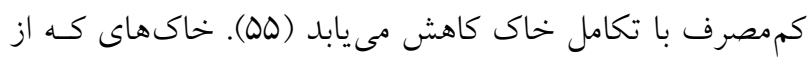

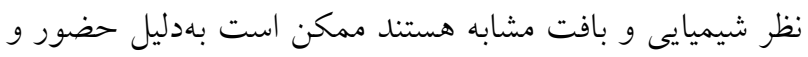

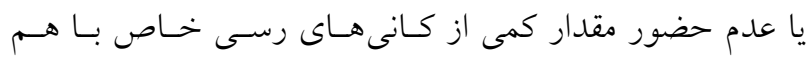

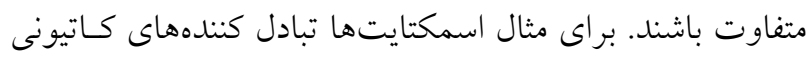

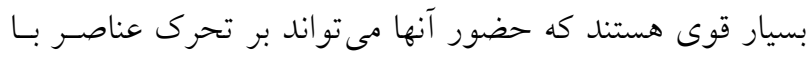

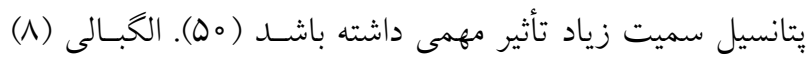

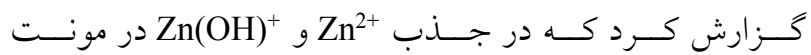

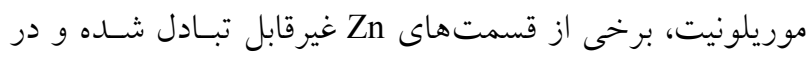

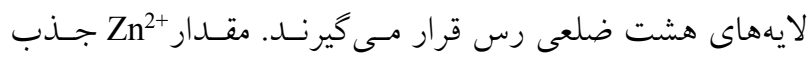

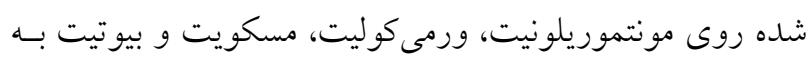

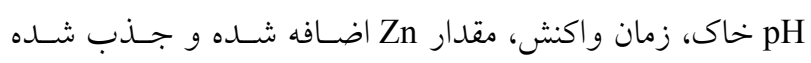

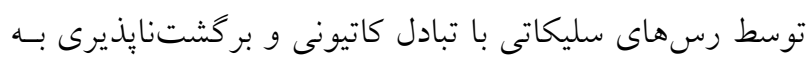

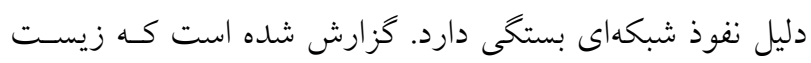

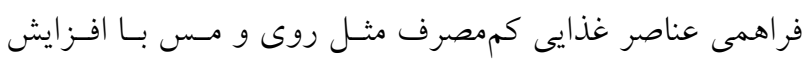

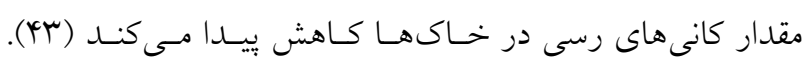

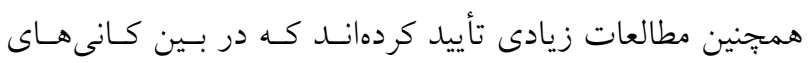

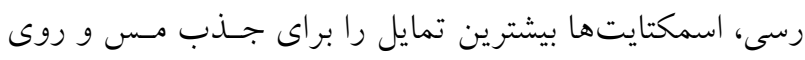

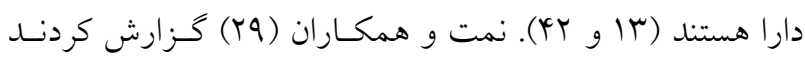
كه با افزايش غلظت روى بر كانى مونتموريلونيت، فضاى بـين

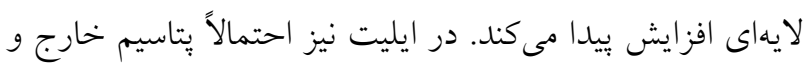

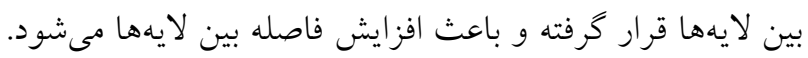

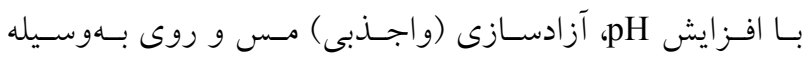

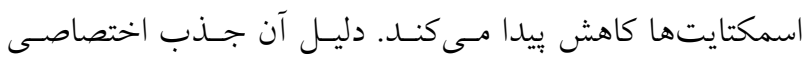


Xpert طبق روش جونز و همكاران (19) و بهكمـك نـرمافـزار

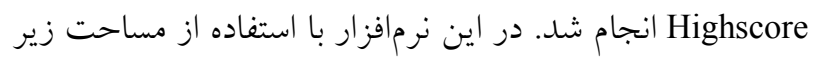

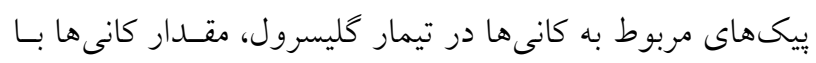

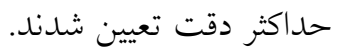

\section{تعيين شكلهاى شيميايى عناصر كممصرف}

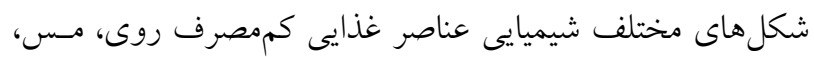

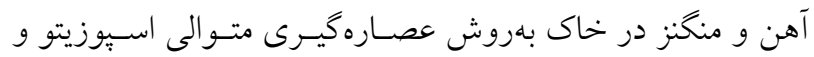

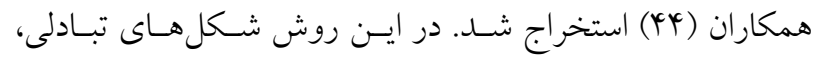

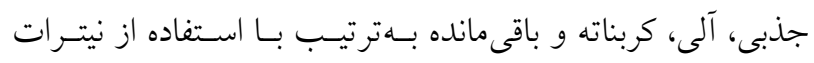
بتاسيم ه/ مولار، آب مقطر دوبار تقطير شده، هيدروكسيد سديم

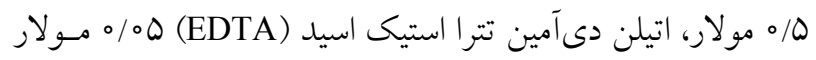

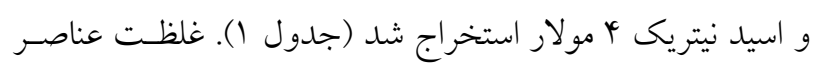

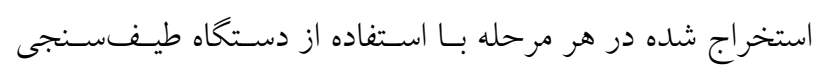

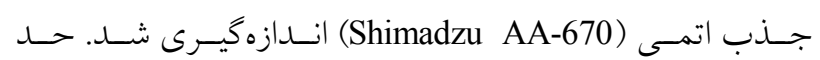

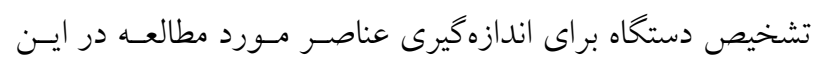

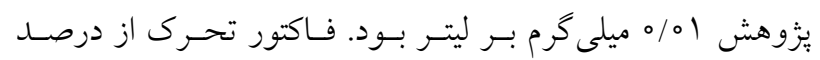

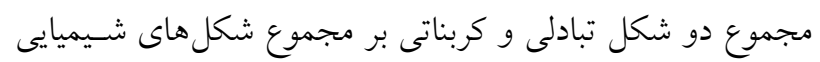

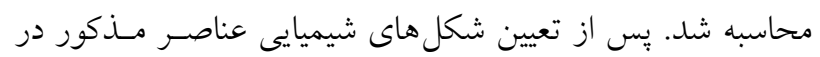

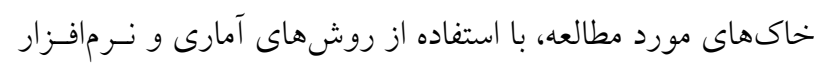

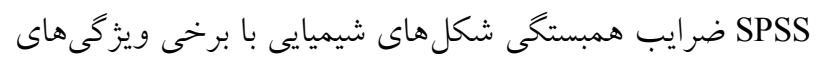
فيزيكى، شيميايى و كانى هاى رسى خاكها محاسبه شد. بلمنظـور

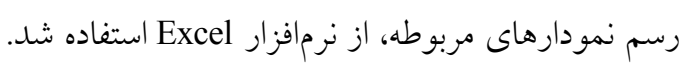

\section{نتايج و بحث}

\section{خصوصيات خاكهاى مطالعه شده}

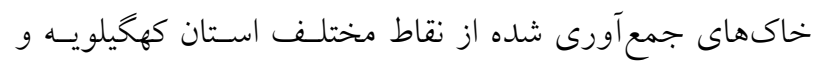
بويراحمد، بهمنظور بررسى وضعيت شكل هاى شيميايى عناصـر

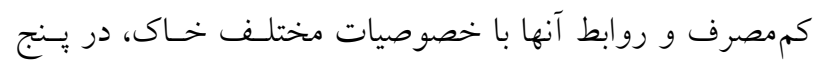

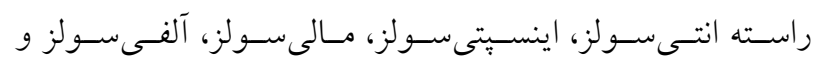

هما متر از سطح دريا اسـت. بـا توجـهـ بـهـ شـرايط جغرافيـايى

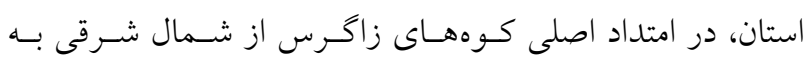

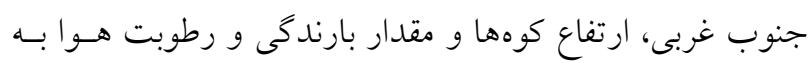

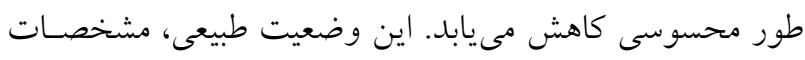

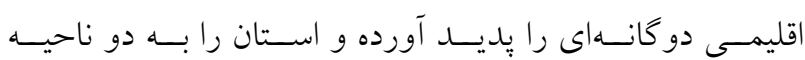
سردسيرى و گرمسيرى تقسيم كرده است.

\section{تجزيههاى فيزيكى، شيميايى و كانىشناسى}

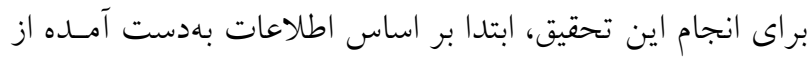

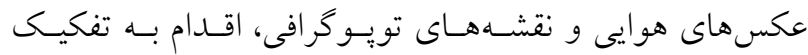
واحدهاى فيزيوكر افى كرده و تعدادى خـاكرخ در ايسن واحســها

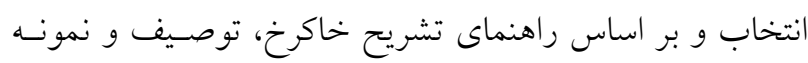

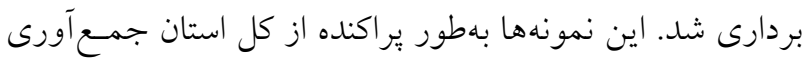

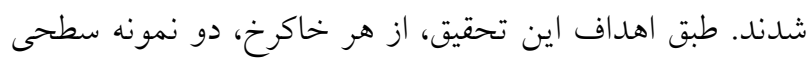

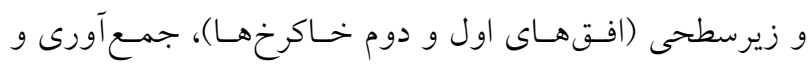

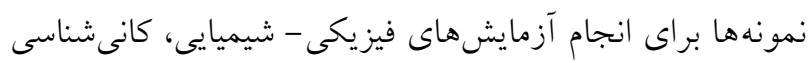

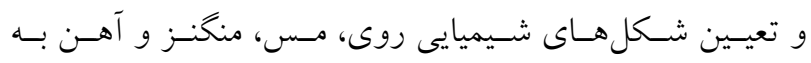

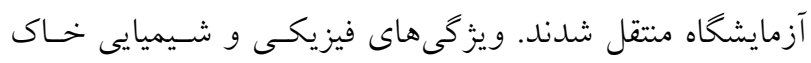

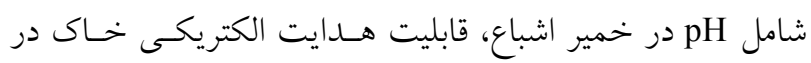

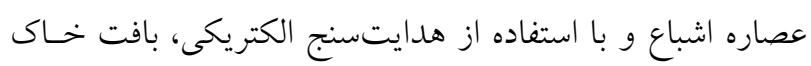
بمروش هيدرومتر (9)، كربنات كلسيم معادل بهروش تيتراسـيون

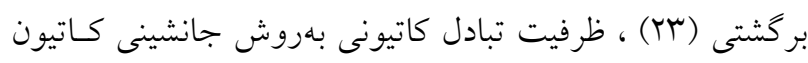

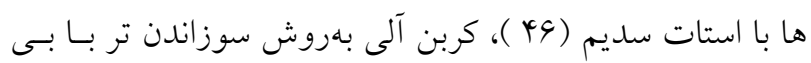

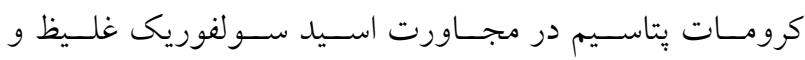

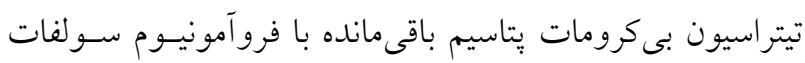

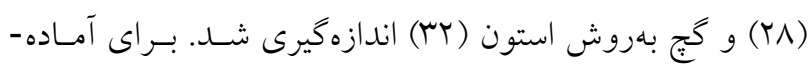

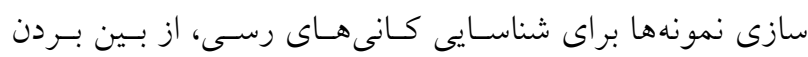

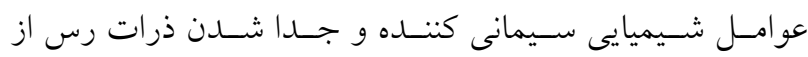

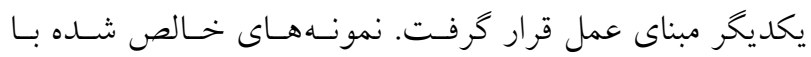

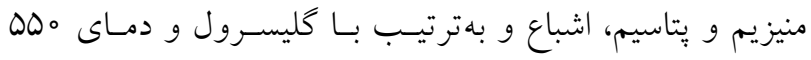

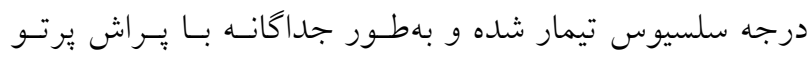

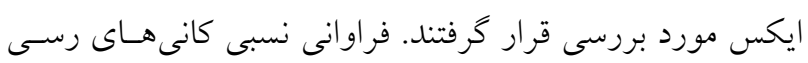


جدول ا. مراحل مختلف عصارهگيرى متوالى شكلهاى مختلف شيميايى عناصر غذايى كممصرف

\begin{tabular}{|c|c|c|c|c|}
\hline غلظت عصارهگير & زمان رسيدن & نسبت خاك & شكل شيميايى & مرحله \\
\hline (مولار) & به تعادل & به عصاره كير & استخراج شده & عصارهكيرى \\
\hline $0.5 \mathrm{M} \mathrm{KNO}_{3}$ & 19 ساعت & T:TQ & تبادلى & 1 \\
\hline $\mathrm{H}_{2} \mathrm{O}$ & r ساعت & r:TQ & جذب سطحى شده* & r \\
\hline $0.5 \mathrm{M} \mathrm{NaOH}$ & 19 ساعت & r:TQ & آلى & r \\
\hline $0.5 \mathrm{M} \mathrm{Na}{ }_{2}$ EDTA & 9 ساعت & T:TO & كربناتى & $r$ \\
\hline $4 \mathrm{M} \mathrm{HNO}_{3}$ & 19 ساعت & T:TQ & باقى مانده & 0 \\
\hline
\end{tabular}

*سه مرتبه عصاره گيرى شد.

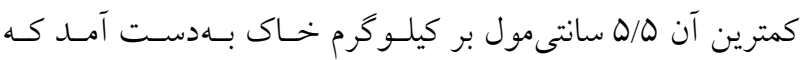

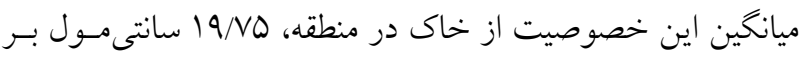

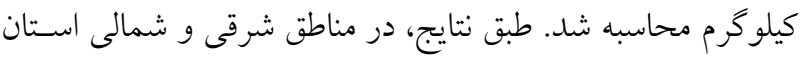
كه بارندكى بيشترى وجود دارد، ميزان رس بيشترى مشاهده شـد.

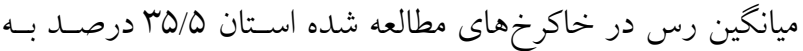
دست آمد كه اين خصوصيت از خاك در خاكهاى مورد مطالعـه

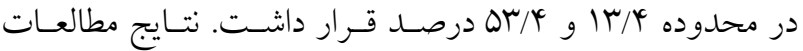
كذشته از كانىشناسى خاكهاى منطقـه مـورد مطالعـه نشـان داده است كه اسمكتيت، ايليت، كلريت، ورمىكوليت، باليخورسكيت و

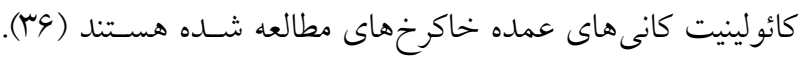

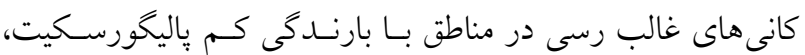

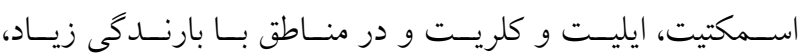

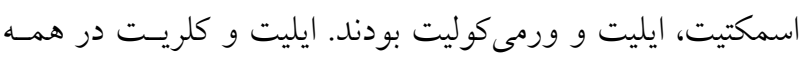
افقهاى سطحى و زيرسطحى خاكرخ خاى مطالعهه شــده مشـاهده

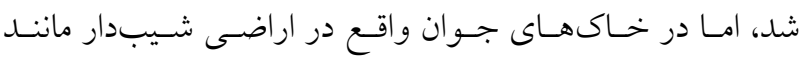

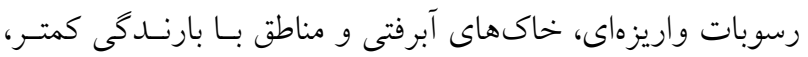

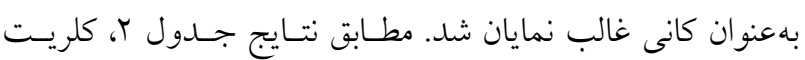

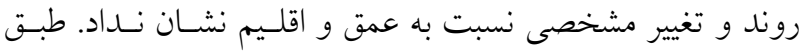

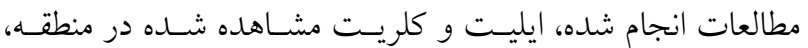

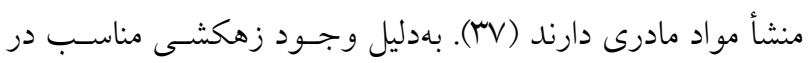
همه خاكرخ ها، علاوه بر حضور اسمكتيت در مواد مادرى، تبــيل ساير كانى ها مانند ايليت و باليخورسكيت به اسمكتيت مىتواند از

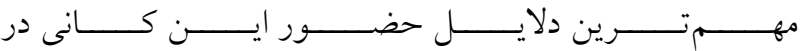

ورتى سولز طبقهبندى شدند (جدول Y)، كه تنوع بهدست آمده از راستههاى خاك مورد مطالعه در اين تحقيق، مىتواند در تفسسير

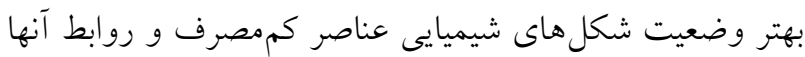
با خصوصيات مختلف خاك، كمكى كنــ. برخسى خصوصسيات فيزيكى و شيميايى خاكهاى مورد مطالعـه در جـدول r نشـان

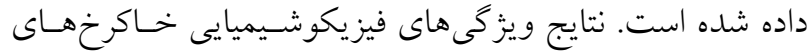

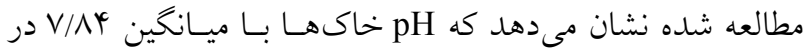
محدوده خنثى و بازى ضعيف (V/Y تا V/ ) قرار دارند. مقــادير قابليت هدايت الكتريكى در نمونه خاكهــاى مـورد تحقيـق، در محدوده //ه تا // دسى زيمنس بر متر (ميـانخين 90/ه دسى زيمنس بر متر) بهدست آمده، كه نشان از عدم شورى خاكهاى ترى منطقـه دارد. مقـادير زيـاد از ميـانخين كربنـات كلسـيم معـادل (FV/Fr)

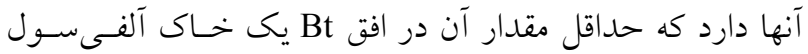

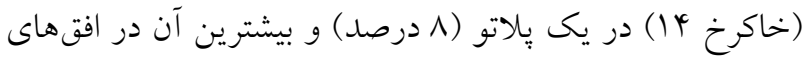

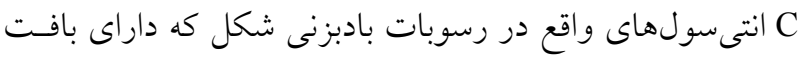

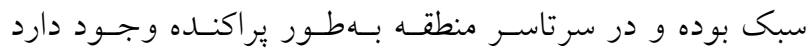

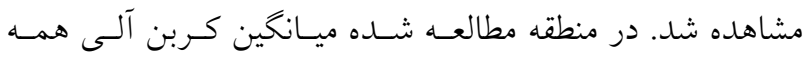

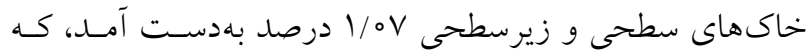

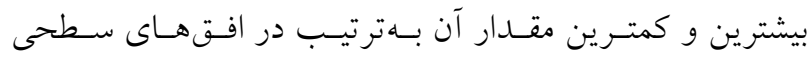

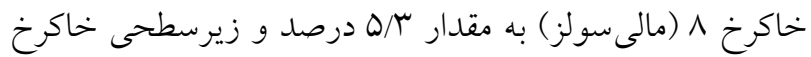

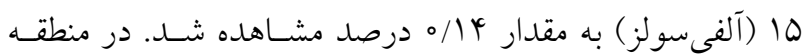

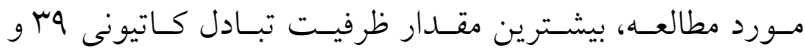


نشريه علوم آب و خاك / سال بيست و جِهارم / شماره جِهارم / زمستان 94ه1

جدول r. تعدادى از خصوصيات فيزيكوشيميايى خاكهاى مطالعه شده و تجزيه نيمه كمى كانىهاى رسى در منطقه مورد مطالعه

\begin{tabular}{|c|c|c|c|c|c|c|c|c|c|c|c|c|c|c|c|c|c|}
\hline رده بندى & فيزيو كرافى & $\mathrm{Pal}^{*}$ & Каo* & Ver* & $\mathrm{chl}^{*}$ & Ill* & Sme* & $\begin{array}{c}\text { CEC (cmol } \\
\mathrm{kg}-1)\end{array}$ & $\begin{array}{c}\text { آلى (\%) } \\
\text { (\% }\end{array}$ & $\begin{array}{l}\mathrm{CCE} \\
(\%)\end{array}$ & بـ & $\begin{array}{l}\text { ر\%) } \\
\end{array}$ & $\begin{array}{l}\text { سيلت } \\
\%)\end{array}$ & $\begin{array}{l}\text { ش) } \\
\text { (\%) }\end{array}$ & افق & شماره & شاكرخ \\
\hline \multirow{2}{*}{$\begin{array}{c}\text { Typic } \\
\text { Haplustolls }\end{array}$} & دشت دامنه & ++ & ++ & + & ++ & +++ & +++ & $9 / 10$ & $19 / 1$ & $1 / 44$ & $9 / \mathrm{N}$ & $\mathrm{V} / \mathrm{rq}^{\mathrm{S}}$ & re & $r / T V$ & Ap & 1 & \multirow[t]{2}{*}{1} \\
\hline & اى ای & ++ & + & + & ++ & ++ & +++ & ir & $9 \mathrm{~V} / 0$ & $9 / 90$ & $9 / N$ & r/ro & $9 \pi \circ$ & re & Bw1 & r & \\
\hline \multirow{2}{*}{$\begin{array}{l}\text { Calcidic } \\
\text { Argiustolls }\end{array}$} & حشت & ++ & + & + & ++ & +++ & +++ & $V / r I$ & $\circ N / 1$ & $\varphi / 40$ & NV & $r / T V$ & $r / 4 r$ & $r / 19$ & Ap & $r$ & \multirow{2}{*}{ r } \\
\hline & دامنهاى & ++ & + & + & +++ & ++ & +++ & $4 / 1 \Lambda$ & 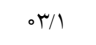 & $r / \varphi_{0}$ & $\wedge$ & $\varphi / 4 \Delta$ & $r / T V$ & $r / M V$ & $\mathrm{~A} / \mathrm{B}$ & $r$ & \\
\hline \multirow{2}{*}{$\begin{array}{c}\text { Aridic } \\
\text { Calciustepts }\end{array}$} & دشت دامنه & ++ & + & + & + & +++ & +++ & $11 / 1$ & $99 / 0$ & $r / \Delta \Delta$ & $V / q$ & $T V / F$ & $\mu \varphi / 9$ & r^ & Ap & 0 & \multirow{2}{*}{$r$} \\
\hline & اى اى & ++ & + & + & + & +++ & ++ & $9 / 4$ & $01 / \%$ & $9 / 0 r$ & $\wedge$ & rY/N & rr & $r r / r$ & Bk1 & 4 & \\
\hline \multirow{2}{*}{$\begin{array}{c}\text { Typic } \\
\text { Ustifluvents }\end{array}$} & رسوبات & + & ++ & + & ++ & ++ & ++ & 14 & $r 4 / 1$ & $r / 90$ & $9 / N$ & $r / T)$ & $r / T V$ & $r / D 1$ & Ap & v & \multirow{2}{*}{ r } \\
\hline & واريزهاى & ++ & ++ & + & ++ & +++ & ++ & $r / N 4$ & $9 / 0$ & Gr & $\mathrm{V} / \mathrm{V}$ & $r / \pi q$ & $9 / \pi 4$ & $4 \varphi$ & $\mathrm{C} 1$ & $\wedge$ & \\
\hline \multirow{2}{*}{$\begin{array}{c}\text { Gypsic } \\
\text { Haplustepts }\end{array}$} & رسوبات & +++ & - & - & ++ & +++ & ++ & $1 / 9$ & $\Delta T / \circ$ & $r / \Delta r$ & $\wedge$ & $V / 19$ & rr & $r / D 1$ & Ap & 9 & \multirow{2}{*}{0} \\
\hline & واريزهاى & ++++ & - & - & ++ & ++ & ++ & IN & $4 \%$ & $9 / 10$ & $9 N$ & $4 / 19$ & $r / T V$ & $r / Q r$ & $\mathrm{C} 1$ & 10 & \\
\hline \multirow{2}{*}{$\begin{array}{c}\text { Typic } \\
\text { Xerofluvents }\end{array}$} & دِت & + & + & + & ++ & + & +++ & IV & $99 / 0$ & $r / 9 r$ & NN & V/rT & res & rr & Ap & 11 & \multirow[t]{2}{*}{4} \\
\hline & آبرفتى & ++ & ++ & - & ++ & ++ & + & $\Delta / \Delta$ & $4 \%$ & $V / 9$ 。 & $r / \Lambda$ & $r / 1 r$ & $r / q$ & $r / N V$ & $\mathrm{C} 1$ & Ir & \\
\hline \multirow{2}{*}{$\begin{array}{c}\text { Calcic } \\
\text { Haploxeralfs }\end{array}$} & \multirow{2}{*}{ بِلاتو } & ++ & + & + & ++ & ++ & +++ & $V / I V$ & $0 / 1$ & $N /{ }^{+1}$ & $9 N$ & $r / T V$ & $r / 40$ & $r / I V$ & Ap & ir & \multirow[t]{2}{*}{ v } \\
\hline & & ++ & + & - & ++ & + & +++ & 10 & $\mathrm{~V} / \mathrm{o}$ & $r / 4 q$ & $\mathrm{~V} / \mathrm{N}$ & $V / \Delta Y$ & $r r$ & $r / 10$ & Btk1 & 14 & \\
\hline \multirow{2}{*}{$\begin{array}{c}\text { Typic } \\
\text { Haploxerolls }\end{array}$} & \multirow{2}{*}{ بֶلاتو } & - & ++ & + & ++ & ++ & +++ & rq & $r \Delta / \Delta$ & $r / r v$ & $\Psi / N$ & $r / T V$ & r & $r / T V$ & A & 10 & \multirow{2}{*}{$\wedge$} \\
\hline & & - & ++ & - & ++ & ++ & +++ & rr & $\kappa r / l$ & $9 / 04$ & $9 / N$ & $r / r v$ & rr & $r / T V$ & $\mathrm{Bw}$ & 19 & \\
\hline \multirow{2}{*}{$\begin{array}{l}\text { Chromic } \\
\text { Calcixererts }\end{array}$} & دشت & - & + & ++ & + & ++ & +++ & $1 / \pi \circ$ & $\mid k / 1$ & $V / q$ & $N V$ & $\varphi / 4 \Delta$ & $r / r q$ & $r / 10$ & Ap & IV & \multirow{2}{*}{9} \\
\hline & آبرفتى & - & ++ & + & ++ & + & +++ & $1 / r \circ$ & $\psi / 0$ & $9 / 1 \mathrm{~V}$ & $N V$ & $r / 4 q$ & $9 \pi$ & $9 / 19$ & Bkss1 & 11 & \\
\hline \multirow{2}{*}{$\begin{array}{c}\text { Aquic } \\
\text { Haploxerepts }\end{array}$} & دشت & + & ++ & + & + & + & ++++ & $V / r q$ & $r \& / 1$ & $r / r_{0}$ & $N V$ & V/AT & rr & $r / 10$ & Ap & 19 & \multirow{2}{*}{10} \\
\hline & آبرفتى & - & ++ & + & - & - & ++++ & $N / r)$ & $\mathrm{kV} / 0$ & $r / I V$ & $N V$ & $r / 4 q$ & r/r & $r / I V$ & $\mathrm{Bg} 1$ & ro & \\
\hline \multirow{2}{*}{$\begin{array}{c}\text { Calcic } \\
\text { Haploxeralfs }\end{array}$} & دشت & - & ++ & ++ & + & + & ++++ & $r / T \psi$ & $94 / 1$ & or & $\mathrm{V} / \mathrm{V}$ & $\mathrm{V} / \mathrm{r} \Lambda$ & $\mu \psi$ & $r / l v$ & Ap & YI & \multirow{2}{*}{11} \\
\hline & آبرفتى & - & + & ++ & - & - & ++++ & $r / r)$ & $v 9 / 0$ & $r / \Delta \Delta$ & $\wedge$ & $\varphi / \Delta \Delta$ & rro & $r / q$ & Btk1 & rr & \\
\hline Typic & دشت & ++ & - & ++ & ++ & ++ & +++ & $Q / T \Delta$ & $11 / r$ & $1 / 4 \wedge$ & $\mathrm{V} / \mathrm{V}$ & $\mathrm{V} / \mathrm{ru}_{\mathrm{r}}$ & $r_{0}$ & r/so & Ap & r & 15 \\
\hline Haploxerolls & آبرفتى & - & - & ++ & +++ & ++ & ++ & $1 / \pi \Delta$ & $\mathrm{Vq} / \mathrm{o}$ & $r / 40$ & Q/N & $r / \mu 1$ & $r / T r$ & $r / \% \sigma$ & $\mathrm{C} 1$ & re & 11 \\
\hline Typic & رسوبات & + & - & ++ & ++ & ++ & +++ & $9 / 9$ & $90 / \%$ & $9 / 90$ & $\wedge$ & $r / r r$ & $9 / 19$ & $Q / D G$ & Ap & ro & $1 \pi$ \\
\hline Xerorthents & واريزهاى & ++ & - & + & ++ & ++ & +++ & $r / q$ & $01 \%$ & $N / 9 V$ & $\wedge$ & V/rT & $r / 19$ & $\Delta \Lambda$ & C & rq & \\
\hline $\begin{array}{l}\text { Mollic } \\
\text { and }\end{array}$ & ليلاتو & - & ++ & ++ & - & +++ & ++++ & $1 / \pi 。$ & $M N / \circ$ & $r / r_{0}$ & $\wedge$ & $V / 4 \varphi$ & $r_{\Lambda}$ & $r / 10$ & Ap & TV & 14 \\
\hline Haploxeralfs & & - & + & +++ & - & ++ & +++ & r/ro & $19 / 1$ & $1 / \wedge$ & NV & $r / \Delta V$ & $r / r$ & $r / 11$ & $\mathrm{Bt} 1$ & rA & \\
\hline Calcic & يلاتو & ++ & + & ++ & - & ++ & +++ & $1 / T \Delta$ & 1911 & $N /{ }^{*} V$ & NV & $r / T \Delta$ & $r / r q$ & o & Ap & ra & 10 \\
\hline Haploxeralfs & 8 & + & + & ++ & - & + & ++++ & $r / T r$ & $1 \% \%$ & $r / 4+1$ & $\wedge$ & $V / 0$ 。 & rq & $r / \pi r$ & Btk & $r_{0}$ & \\
\hline 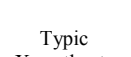 & رسوبات & + & ++ & - & +++ & + & +++ & $r / r)$ & $r V / 1$ & $9 / r r$ & $9 / \mathrm{V}$ & $V / r y$ & rq & $r / r q$ & A & m & 19 \\
\hline Xerorthents & واريزهاى & ++ & ++ & + & +++ & ++ & ++ & $\Delta / \Delta$ & $r / 0$ & N/Ar & $9 N$ & $r / \mu r$ & $9 / 1$ & v^ & $\mathrm{Cl}$ & rr & \\
\hline
\end{tabular}


و هيدروكسيدهاى آهن غيرمحلول بيـان كردنـــ. عـدم وجـود

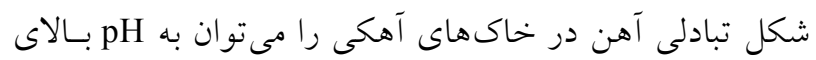

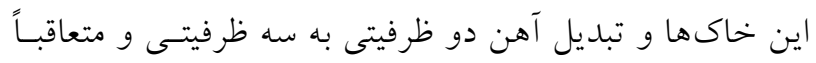

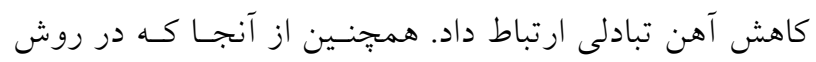

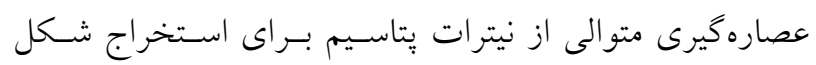

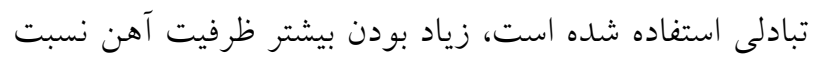

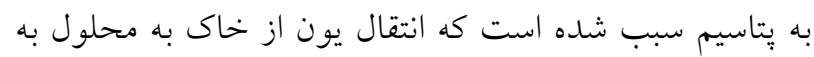

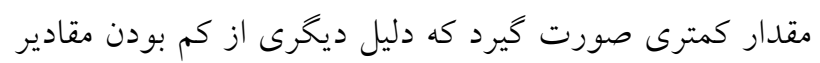

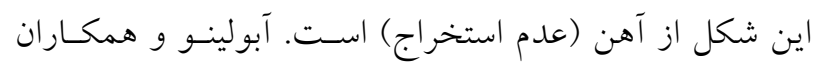

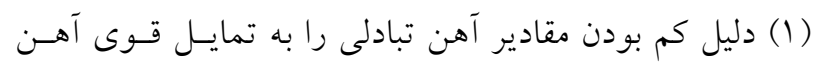
براى تبديل شــدن بـه شـكل اكسـيدى و هيدرو كسـيدى بيـان

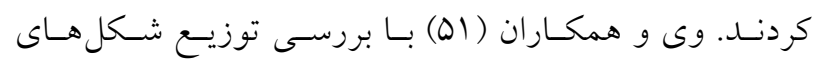

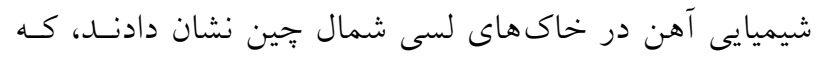

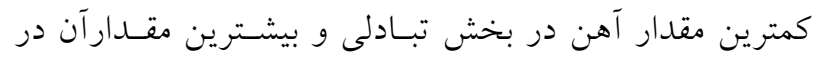

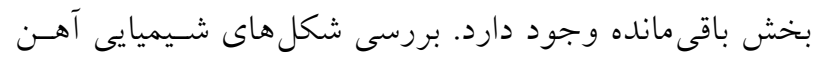

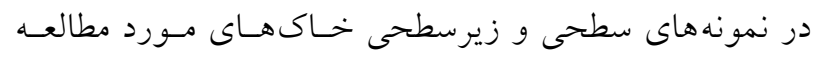

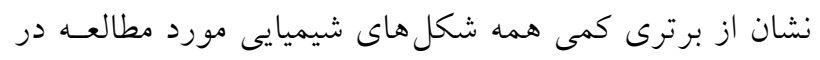
نمونههاى سطحى نسبت به نمونههاى زيرسطحى، داشته است.

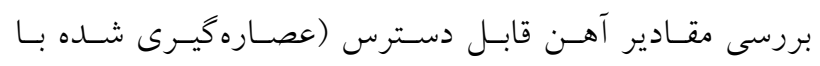

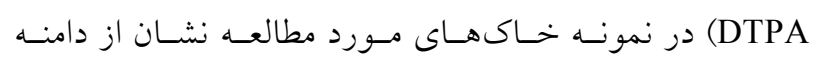

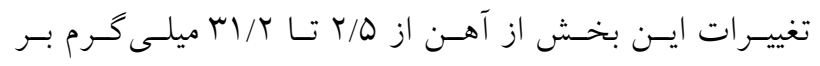

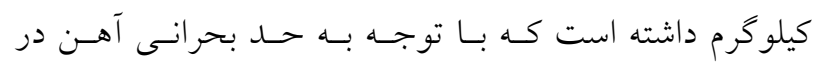

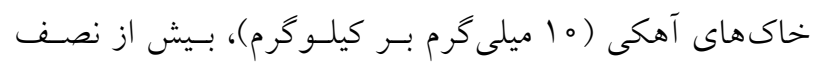

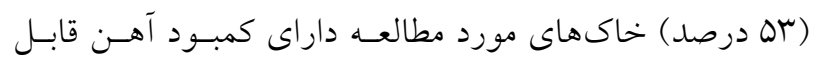

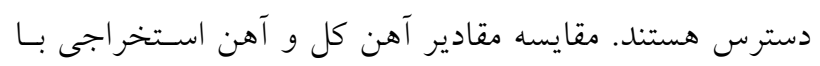

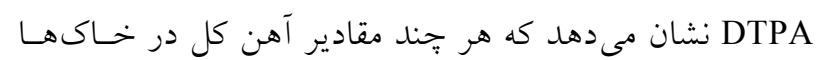

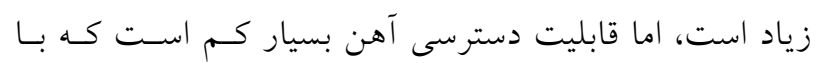

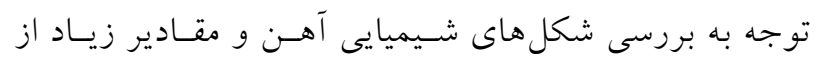

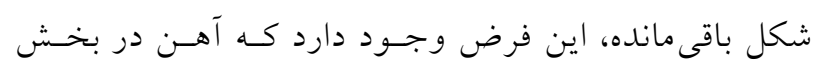

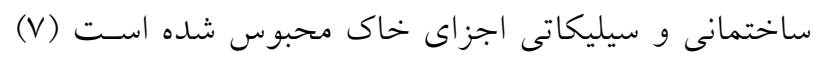

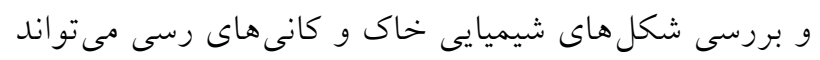

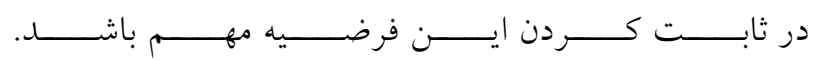

خاك ها و بهخصوص در بخشهاى مرطوبتر استـان باشـــ. در

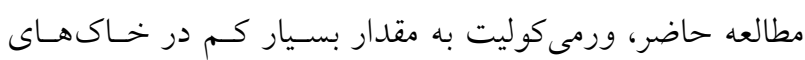

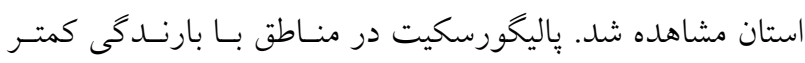

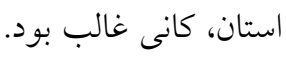

شكلهاى شيميايى عناصر غذايى كممصـرف در خــاكهـاى مورد مطالعه جدول r ميانكين غلظـت هـــ شـكل از شـكل هــاى شـيميايى

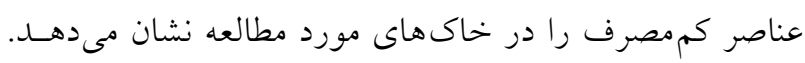

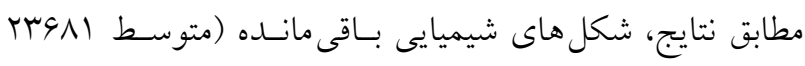

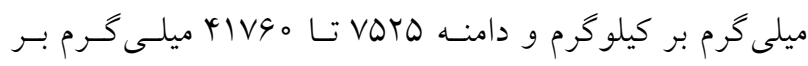

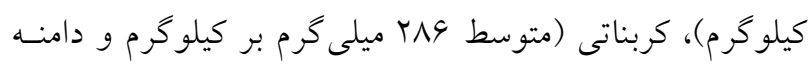

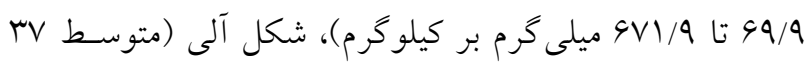

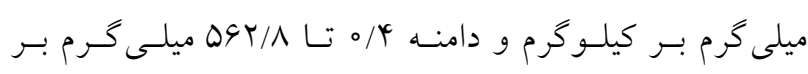

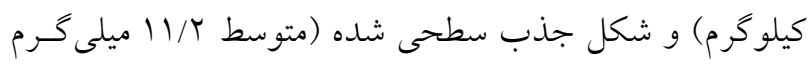

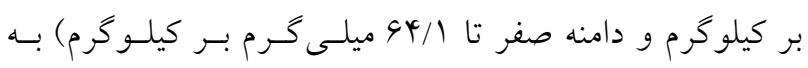

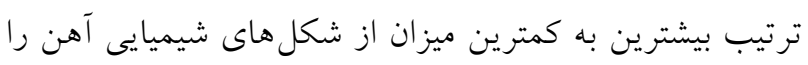

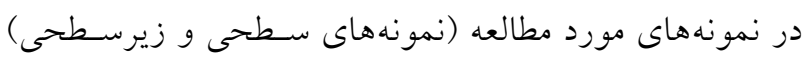

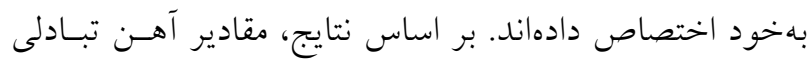
در همه نمونه هاى مورد مطالعه، كمتر از حد تشخيص دستخاه

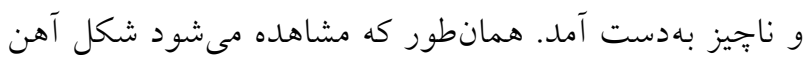

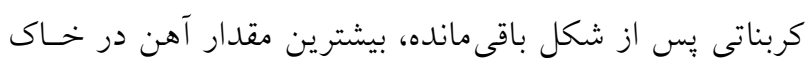

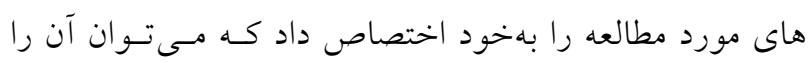

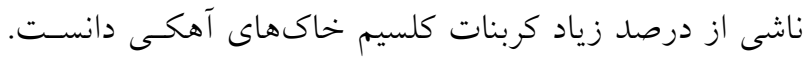

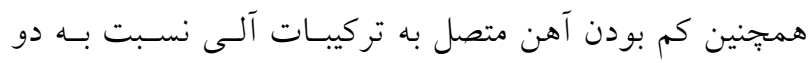

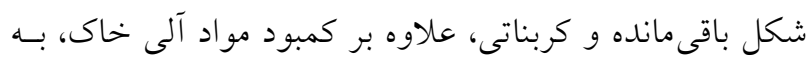

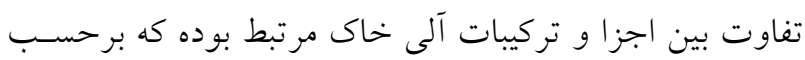

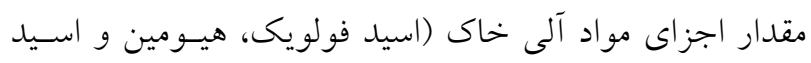

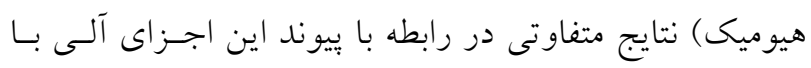

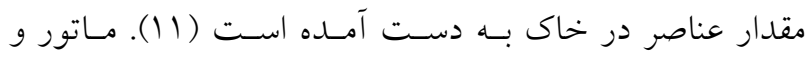

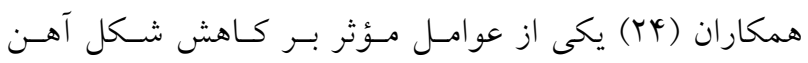

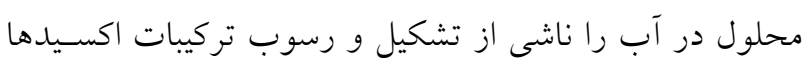




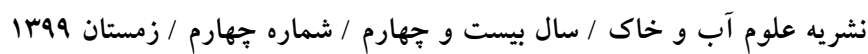

جدول r. ميانخين توزيع عناصر كممصرف در افقهاى سطحى و عمقى راستهاى خاكهاى مطالعه شده

\begin{tabular}{|c|c|c|c|c|c|c|c|c|c|c|c|c|c|c|}
\hline $\begin{array}{c}\text { DTP } \\
\text { A }\end{array}$ & كل & باقىماند & كربناتى & آلى & سطجى & تبادلى & DTPA & كل & باقىماند & كربناتى & آلى & سطحى & تبادلى & شاكرخ \\
\hline & \multicolumn{5}{|c|}{ مس } & & & \multicolumn{5}{|c|}{ روى } & & \\
\hline $1 / 9$ & $I V / r$ & 10 & $r / 9$ & $r / v$ & - & - & $0 / 1$ & $V Y / V$ & $9 V / 4$ & $4 / 9$ & $0 / 0$ & - & -* & 1 \\
\hline$r / r$ & $T Y / Q$ & $\mid T / 1$ & $\Delta / \mu$ & $\Delta / r$ & - & - & $0 / 9$ & $\Lambda 1 / r$ & $V Q / 4$ & $\Delta / \Lambda$ & $0 / 1$ & - & - & r \\
\hline$\circ / V$ & $10 / V$ & $11 / 9$ & r & $1 / 9$ & - & - & $0 / r$ & $V Y / V$ & $99 / 9$ & $Q / T$ & $0 / 9$ & - & - & $r$ \\
\hline$\circ / 9$ & $19 / \mathrm{V}$ & $10 / V$ & $r / l$ & $r / 9$ & - & - & $0 / 9$ & $V V / r$ & $99 / \pi$ & $9 / 1$ & $1 / r$ & - & - & r \\
\hline $0 / 9$ & ir & 9 & $T / l$ & $1 / 9$ & - & - & $0 / 1$ & $\Delta Q / 4$ & 01 & $\Gamma / \Lambda$ & $\circ / V$ & - & - & 0 \\
\hline $0 / 9$ & $1 \pi / r$ & $\Lambda / \Lambda$ & $T / T$ & $r / \mu$ & - & - & $0 / r$ & $\Delta Q / q$ & $01 / N$ & $r / 9$ & $0 / \mu$ & - & - & 4 \\
\hline $1 / V$ & $T Y / Q$ & $10 / N$ & $\mu / \mu$ & $4 / 9$ & - & - & $0 / 0$ & $9 r / 9$ & $\Lambda V / \mu$ & $\psi / \Lambda$ & $\circ / \Lambda$ & - & - & v \\
\hline $1 / r$ & $r M / l$ & $\mid r / 4$ & $\varphi / \Lambda$ & $r / q$ & - & - & $r / r$ & $90 / 1$ & $\Lambda \mu / N$ & $9 / r$ & $T / T$ & - & - & $\wedge$ \\
\hline $1 / 1$ & $T Y / l$ & $10 / 9$ & 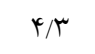 & $r / r$ & - & - & $1 / r$ & $10 r / 4$ & $99 / \pi$ & $9 / 4$ & $\circ / V$ & - & - & 9 \\
\hline r & $r V / D$ & $\mid 1 / 1$ & $\Psi / V$ & $\psi / \Lambda$ & - & - & r & $119 / \mathrm{V}$ & $104 \pi$ & $11 / 9$ & $0 / 9$ & - & - & 10 \\
\hline $1 / 1$ & $19 / r$ & $11 / 4$ & $r / \Lambda$ & $4 / 1$ & - & - & $0 / 4$ & $9 \circ / V$ & $9 \mathrm{~V} / 9$ & $Y / V$ & $\circ / 0$ & - & - & 11 \\
\hline $1 / 1$ & $r M / l$ & $|r /|$ & $r / q$ & $\Delta / r$ & - & - & $r / r$ & $99 / 1$ & $M$ & $9 / \pi$ & $T / V$ & - & - & Ir \\
\hline$\circ / \Lambda$ & $1 \pi / 9$ & $V / 4$ & r & $r / 9$ & - & - & $\circ / V$ & $G T / r$ & $49 / r$ & $11 / 1$ & $1 / \mu$ & - & - & ir \\
\hline$r / V$ & $M / / 9$ & $\mathrm{IV} / \mathrm{A}$ & $V / 4$ & $9 / 0$ & - & - & $\circ / \mu$ & $1 K r / 9$ & $110 / 1$ & $V / V$ & $\circ / 4$ & - & - & it \\
\hline$\circ / V$ & $M / T$ & $1 Y / 9$ & $r / \Lambda$ & $r / Q$ & - & - & $\circ / \mu$ & $9 \circ / V$ & $\Lambda Q / V$ & $4 / 9$ & $\circ / 0$ & - & - & 10 \\
\hline.$/ 9$ & $I T / T$ & $q / r$ & $r / r$ & $r / V$ & - & - & $0 / r$ & $V r / r$ & $99 / 4$ & 4 & $1 / 1$ & - & - & 19 \\
\hline \multirow[t]{2}{*}{$1 / 4$} & $19 / 0$ & Ir & $r / \Lambda$ & $r / v$ & - & - & $\circ / \Lambda$ & $\wedge Q / 1$ & $V G / 9$ & $9 / 4$ & $\circ / 9$ & - & - & ميانكَين كل \\
\hline & \multicolumn{5}{|c|}{ منخنز } & & & \multicolumn{5}{|c|}{ آهن } & & \\
\hline$q / r$ & $r 99$ & ro。 & 19 & $0 / \mu$ & - & - & 10 & $r \circ V \wedge l$ & Y०YAK & rqo & $r / \varphi$ & $r q / r$ & - & 1 \\
\hline $9 / 1$ & $r \circ \Lambda$ & ror & $\Delta r$ &.$/ 0$ & - & - & ro & TGKYA & $r 9011$ & Y 10 & $9 / 9$ & $\Delta / \Lambda$ & - & r \\
\hline$q / \Gamma$ & $\varphi \circ \Delta$ & rvi & r & $\circ / V$ & - & - & $0 / 1$ & INאN & INTKG & 101 & I/ & $4 / 1$ & - & r \\
\hline $\mid r / A$ & rqv & my & Or & 1 & - & - & $0 / 1$ & rorqu & YOYYY & $|r|$ & $V / \mu$ & $\mid r / x$ & - & r \\
\hline $9 / 9$ & ג & $r \circ q$ & r & $\circ / 0$ & - & - & $0 / 9$ & $1+9 \wedge 0$ & IrNkE & 110 & $\circ / \Lambda$ & rq & - & 0 \\
\hline $\mid r / 1$ & TMT & ral & 41 & $\circ / \Lambda$ & - & - & r & IOTO. & IDITO & 114 & $1 / 1$ & - & - & 4 \\
\hline $19 \mathrm{~N}$ & oVA & DrG & or & $0 / 4$ & - & - & $9 / 9$ & TMAVY & YND० & TVG & $r / c$ & $1 / 1$ & - & v \\
\hline$r q / 9$ & $\Delta 01$ & 410 & זrו & $\Lambda / \Lambda$ & - & - & $14 / 1$ & TETVG & rroiv & $k y$ & $r A D / T$ & $r V / l$ & - & $\wedge$ \\
\hline if & $\Delta V^{\prime}$ & $\Lambda \circ \wedge$ & qr &.$/ 0$ & - & - & $1 N / \Lambda$ & 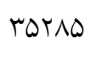 & MYAMT & kts & $\psi / \Lambda$ & $r / r$ & - & 9 \\
\hline $1 T / 9$ & $V Y \circ$ & 909 & 94 & $0 / 0$ & - & - & $19 / 9$ & roDra & $r \Delta \circ V r$ & Yar & $y / 4$ & - & - & 10 \\
\hline $1 T / 9$ & GYY & rVY & or & $0 / 9$ & - & - & $r M / 1$ & rVVAT & TVEYT & r90 & $\varphi / 0$ & $\circ / Y$ & - & 11 \\
\hline$r V / Q$ & OYY & YOS & 90 & $r / \mathcal{A}$ & - & - & $r \circ / V$ & roraq & YYQGYY & 149 & $r \Delta \omega / l$ & $\mu \psi / 4$ & - & Ir \\
\hline$\Lambda / \Delta$ & rVG & rar & $\wedge r$ &.$/ 0$ & - & - & 4 & IFYA & rrMA。 & r/q & $1 / 9$ & $1 V / 9$ & - & r \\
\hline $10 / 4$ & 199 & 991 & rMY & $\circ / \mathrm{V}$ & - & - & $10 / 9$ & rokro & rү991 & सis & r & $r$ & - & 14 \\
\hline$\Lambda / 9$ & $\Delta \Delta \Delta$ & Drr & זr & $\circ / V$ & - & - & $\Lambda / r$ & TOSYA & TOFYO & rII & $r / 9$ & - & - & 10 \\
\hline $9 / 4$ & MyY & r.l & kr & $0 / 1$ & - & - & $\mathrm{V} / \mathrm{I}$ & 19909 & 1940. & 149 & 0 & $k / \varphi^{k}$ & - & 19 \\
\hline $1 \pi / 9$ & $0 \circ V$ & rrq & 91 & $1 / \mu$ & - & - & $11 / 9$ & $Y Y=19$ & rrasl & TAG & rG/A & $11 / r$ & - & ميانكين كل \\
\hline
\end{tabular}




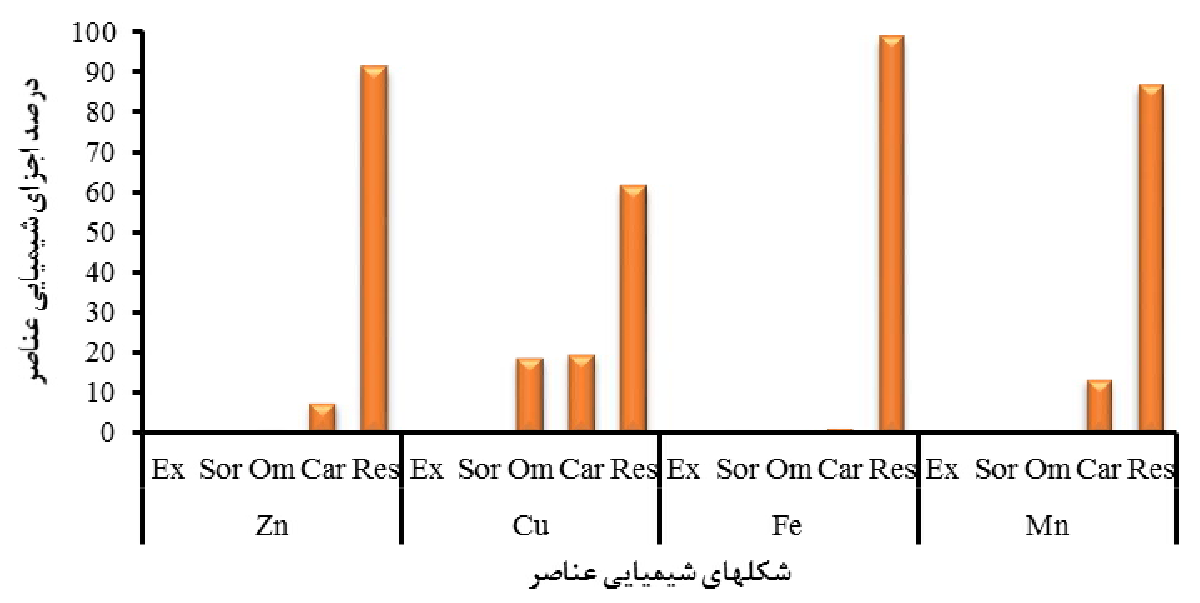

شكل 1. ميانگين جزءهاى شيميايى عناصر غذايى كممصرف در تمام خاكرخهاى مورد مطالعه

اكسيدهاى آهن كريستالى و باقى مانده به ترتيب $91 / 9$ (9)،

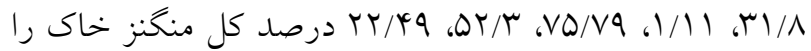
تشكيل دادهاند. والنا و همكاران (OT) در بررسى شكل هاى شـيميايى منخنز

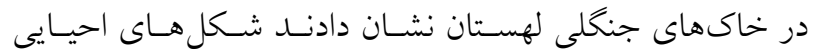
نسبت به ساير شكل ها بيشـترين سـهم از منخنـز را دارا بودنـــ. بررسى مقــادير منخنـز قابـل دسـترس (عصـارهذيـرى شـده بــا (DTPA

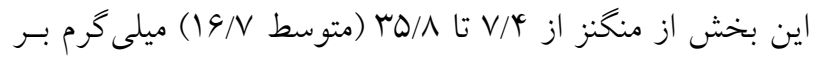
كيلوكرم در خاكهاى سـطحى و 1/T تـا 19/T (متوسط $1 / 9 / 9$ (1)

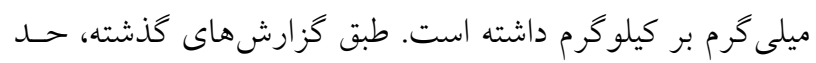
بحرانى منخنز قابل دسترس در خاكهاى آهكى ^ ميلى گـرم بـر كيلوكرم است، كه كمبود منخنز در بس درصد خـاكهـاى مسورد مطالعه مشهود است. بررسى توزيع شكل هاى شيميايى روى در خاكهـاى مـورد

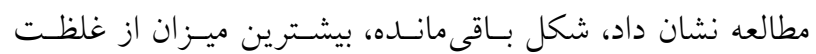

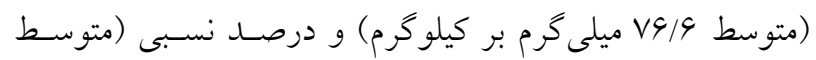

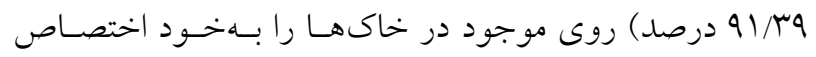
داده اسـت (جــدول بو شـكل (). بـس از شـكل بـاقىمانــه،

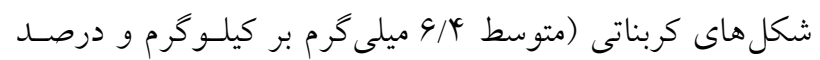
نسبى V/OV درصد) و آلى (متوسط 9 / ه ميلى گرم بر كيلـو گرم و درصد نسبى س// درصد) بهترتيب بيشترين و كمترين ميزان از
مطابق نتايج، شكل هاى شيميايى منخنز در خـاكهـاى مـورد مطالعه (نمونه هاى سطحى و زيرسطحى)، شكل هاى شيميايى

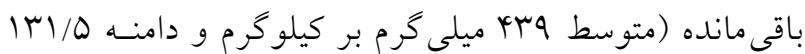

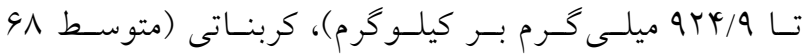

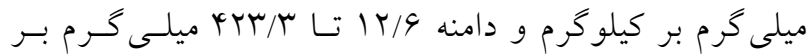
كيلو گرم)، و شكل آلى (متوسط س/1/ ميلى گرم بر كيلـو گرم و

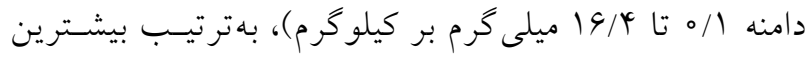

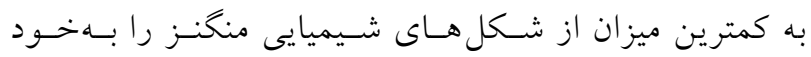
اختصاص دادهاند (جــدول ب). شـكل هـاى تبـادلى و جـــب سطحى شده منخنز، سهمى را بهخود اختصاص نداده و مقدار عصاره گيرى اين شكل ها بسيار نـاجيز و غيرقابـل تشـخيص توسط دستخاه جذب اتمى بودند. بررسى شكل هاى شيميايى منخُز در نمونههاى سطحى و زيرسـطحى خـاكهـاى مـورد

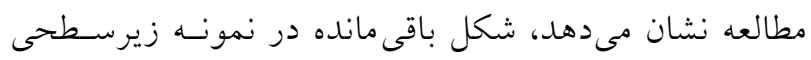
درصد بيشترى از شكل باقى مانده را بهنــود اختصـاص داده

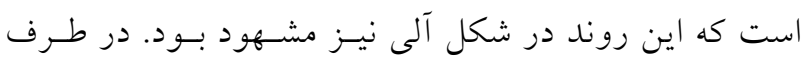
مقابل، شكل كربناتى در نمونه سطحى بيشـتر از زيرسـطحى وجـود داشـت. تابنــده و همكــاران (YVV) در بررسسى توزيـع شكل هاى شيميايى منخنز و ارتباط آنها با شكل قابل جذب و خصوصيات فيزيكى و شيميايى خاكهاى آهكى ايران نشـان دادند مقادير شكل تبادلى، كربناتى، آلى، بهشكل اكسـيدهاى منكنز، متصل بـه اكسـيدىهـاى آهـن بـىشـكل، متصـل بـه 
r اميلى گرم بر كيلوكرم و درصد نسبى 9 ا9 درصـد)، كربنـاتى

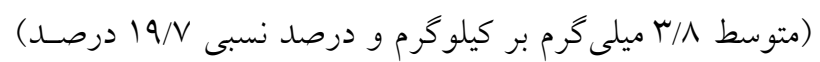

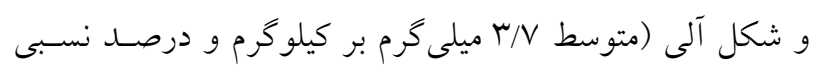

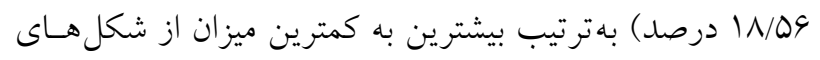

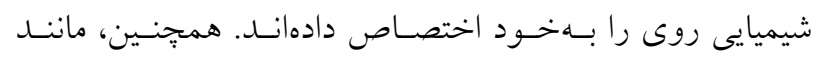

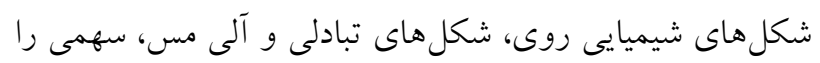
بهخود اختصاص نداده و مقدار عصارهذيرى اين شكل ها بسيار ناجيز و قابل صرفنظر كردن است. در بررسى شكل هـاى شـيميايى مسس، كمـانكر و همكـاران (IV)

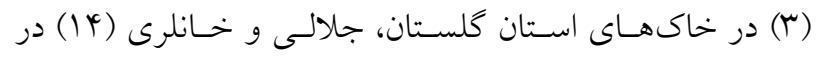

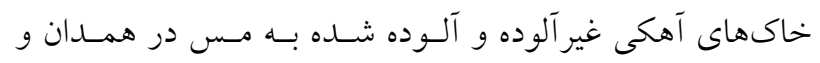

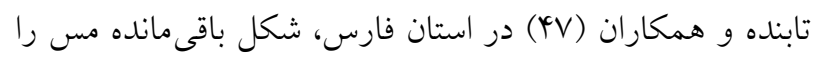

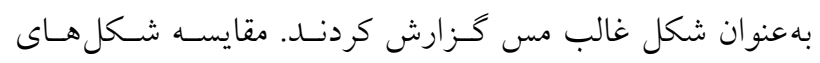

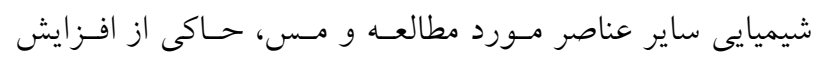

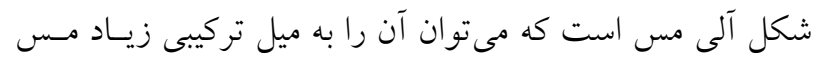

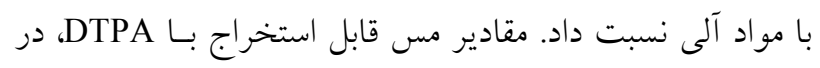

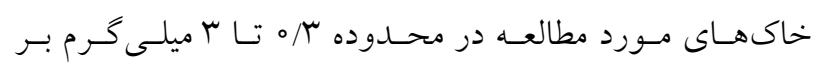

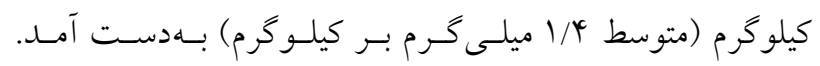

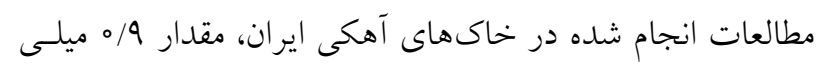

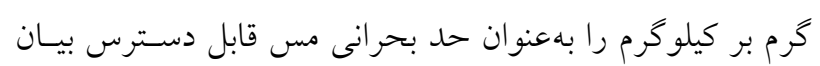

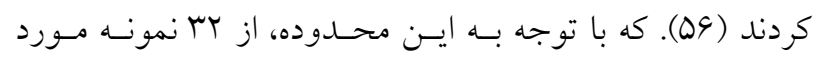

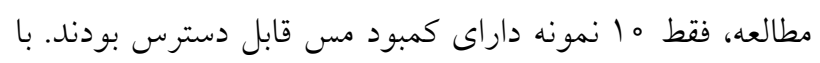

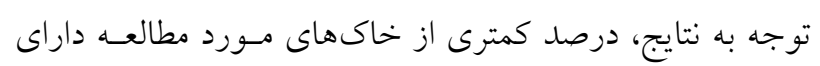

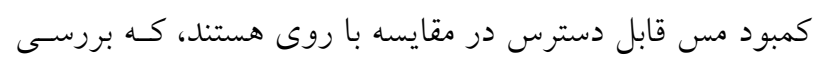

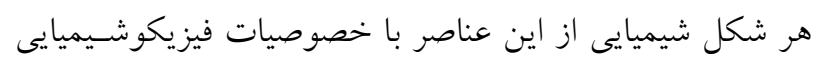

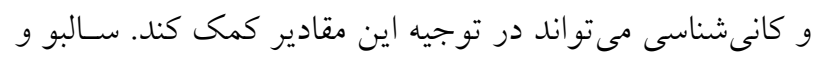

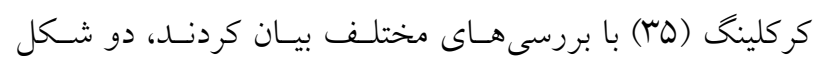

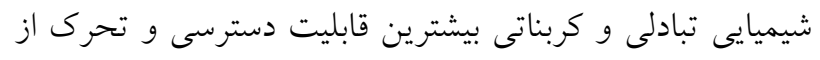

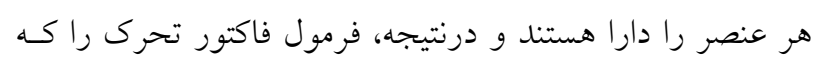

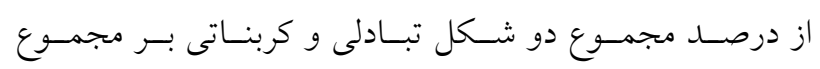
شكلهاى شيميايى محاسبه مىشود، بيشنهاد كردند.
شكلهاى شيميايى روى (قابل اندازميرى توسط دستكاه) را در

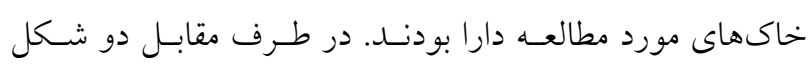
تبادلى و شكل جذب سطحى شده روى بـهدليـل مقـادير بسـيار

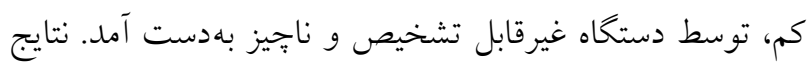

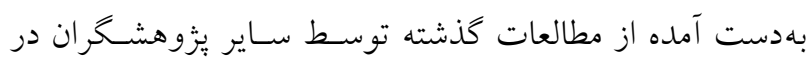

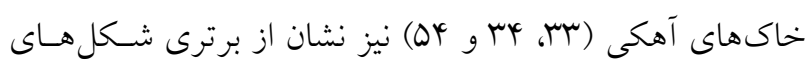

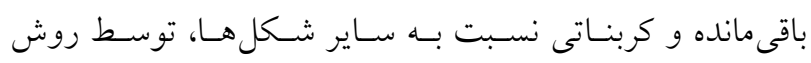

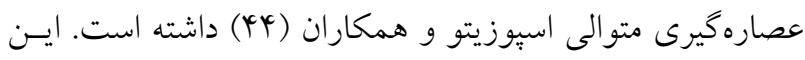

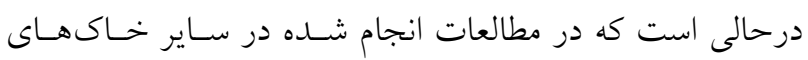

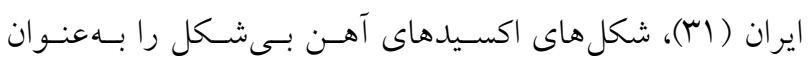

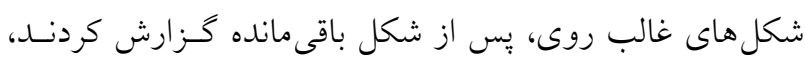

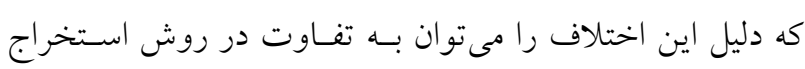
شكلهاى شيميايى روى بيان كرد. بر اساس نتايج بهدست آمــده

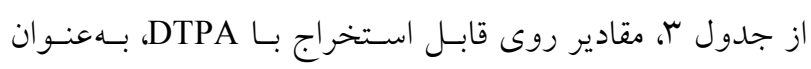

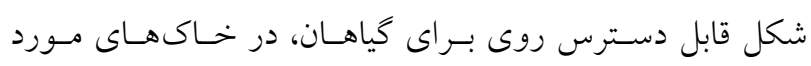

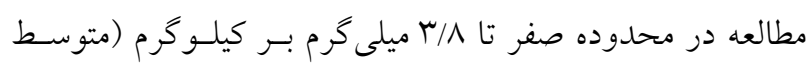

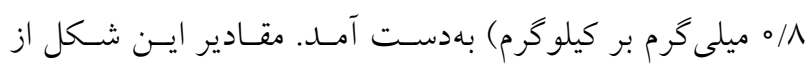

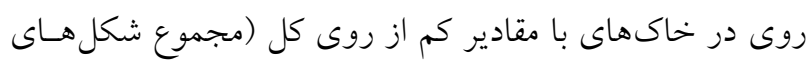

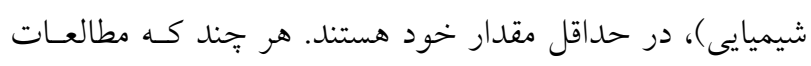

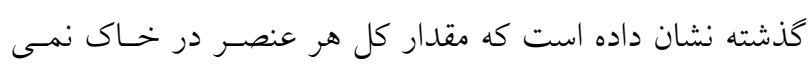

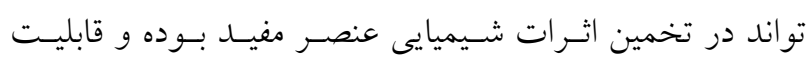
دسترسى عنصر را ييشبينى كند (Yo). برخسى مطالعـات انجـام

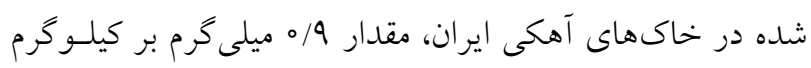

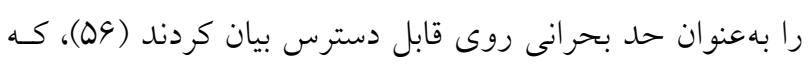

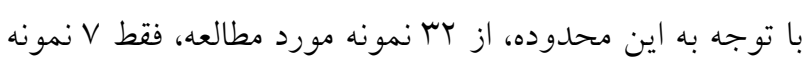

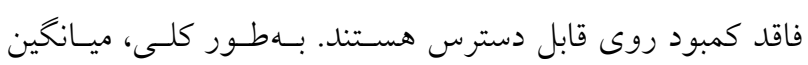

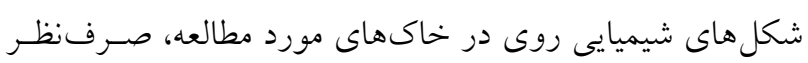

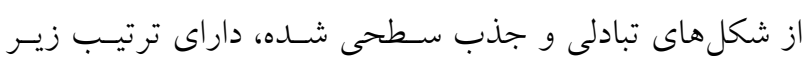
است: آلى > كربناتى >> باقى مانده.

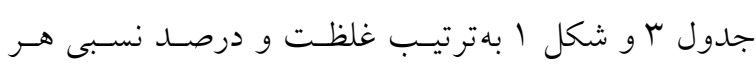

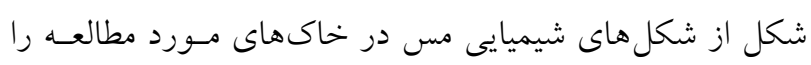

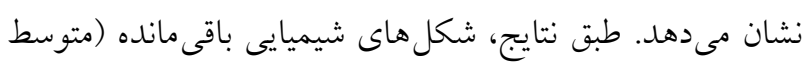




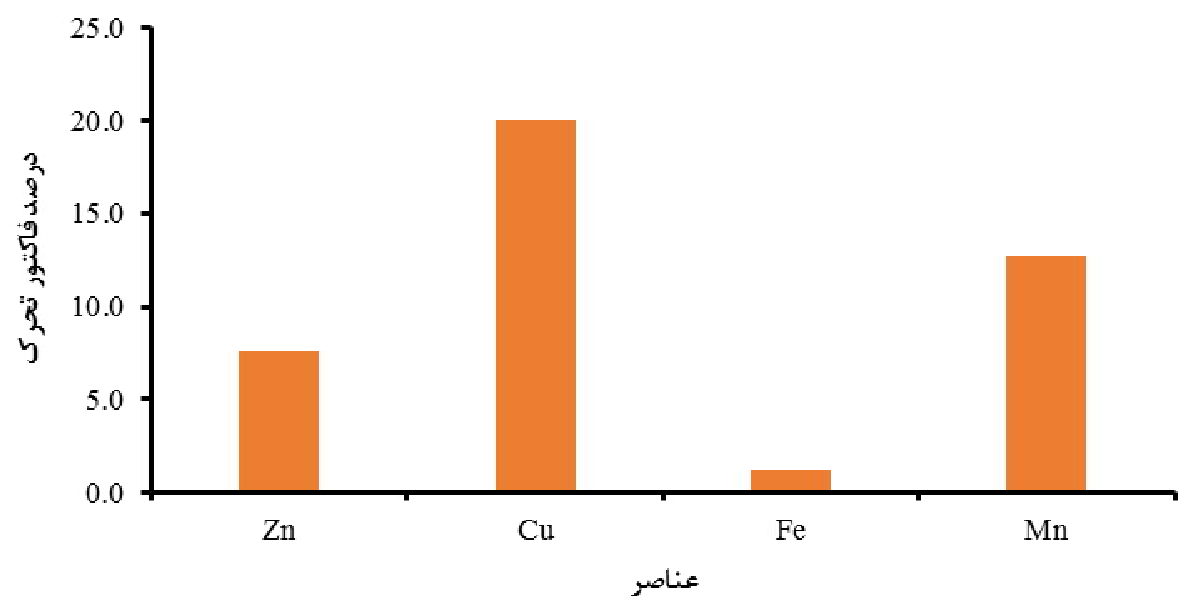

شكل r. ميانگين درصد فاكتور تحر ك عناصر غذايى كممصرف در تمام خاكرخهاى مورد مطالعه

توزيع عناصر كممصرف در راستههـاى مختلـفـ موجــود در منطقه بر اساس نتايج (جدول س) بيشترين مقدار شكل باقىمانده آهـن

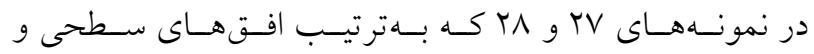

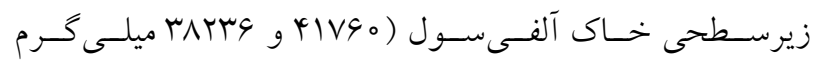

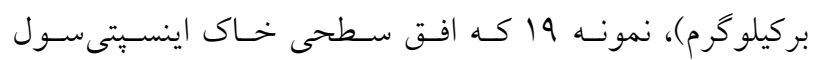

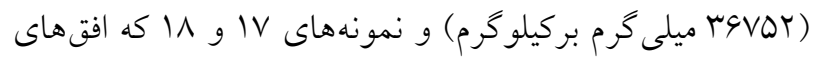
سـطحى و زيرسـطحى خـاك ورتسىسـول ( ميلى گرم بركيلو گرم) هستند، مشاهده شد. كمترين مفـدار شـكل

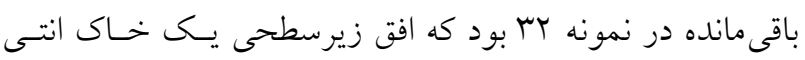
سول (VDTD ميلى گرم بركيلو گرم) است. بيشترين شكل آلى در نمونههاى 10 و بr كه افقهاى سطحى خـاكهـاى مـالى سـول

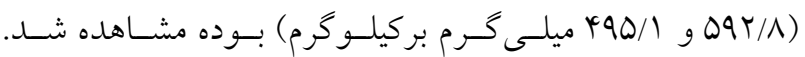

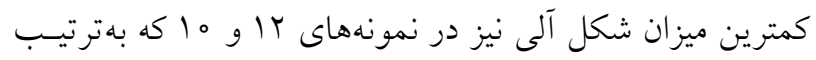
افقهـاى زيرسـطحى خـاكهـاى انتسىسـول (r/r/ ميلى گـرم

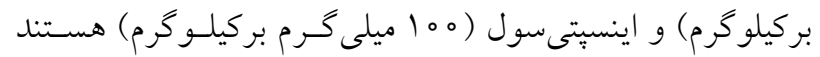

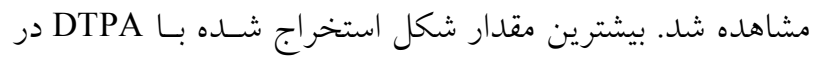

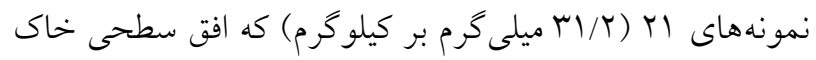

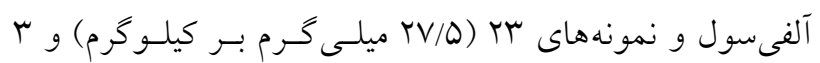

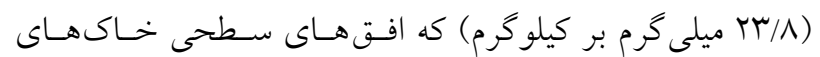
مالى سول هستند مشاهده شد. كمترين مقدار ايسن شـكل نيـز در
بـر اسـاس نتسايج بـهدسـت آمسلد، بيشـترين ميـزان تحسرك عناصرمورد مطالعه در بزّوهش حاضر بهصورت زير بهدسـت

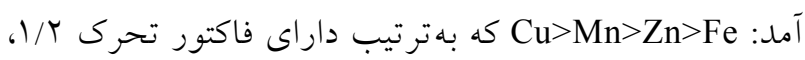

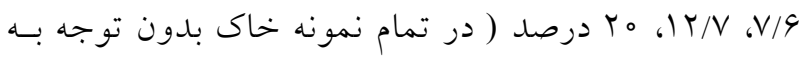
نوع خاكرخ و افق مشخصه) هستند. در مورد عنصر آهن نيـز مى توان كفت كه آهـن نيـز همانــــ آلـومينيم و زيركـونيم از عناصر نادر است، جرا كه اين عنصر در خاى تحرى زيـادى ندارد و يس از هواديدكى كه وارد كـانى هـاى ثانويسه خــاك مىشود، بيشتر در فاز باقى مانده تجمع مى يابد (†人). فـاكتور تحرى به ويزگى هاى زئوشيميايى فلز و در مرتبه بعـدى بـهـ شرايط تشكيل خاك بستخى دارد. طبـق يافتـهــاى تـورى و لو الدو (qq) درصورتى كه فاكتور تحرك كمتـر از •ا درصــ باشد عنصر بهعنوان يك عنصر با تحرك كم، و درصورتى كه اين فاكتور بيشتر از •ه درصد باشد بهعنوان عنصر با تحرى

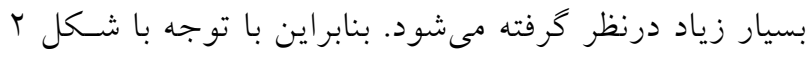
ميزان فاكتور تحرى آهن و روى در نمونههاى مورد مطالعـه. كمتر از • ا درصد بهدست آمد كه نشان از تحسرى كـم ايسن عناصر در خاكهاى منطقه دارد. بنابراين تحرى كـم روى و آهن و تحرى متوسط مس و منخنز در بيشتر خاكهاى مورد

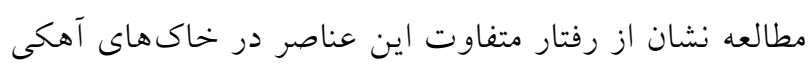
منطقه داشت. 
باقىمانده، نشان از تحرى كم اين عنصر و يا بـهعبـارتى جـذب

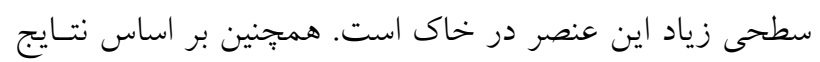

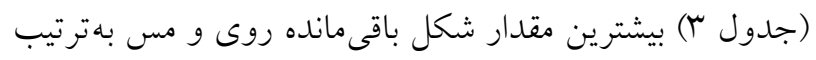

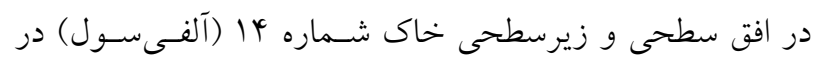
مناطق با بارندگى بيشتر و خاكهاى داراى بافت سنخين تر، مـاده

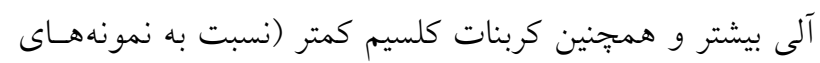

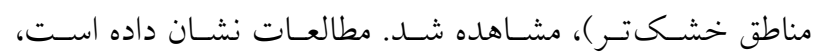

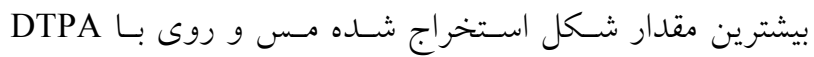

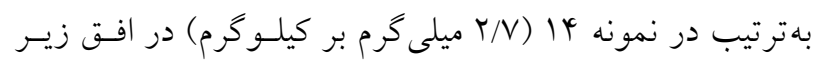

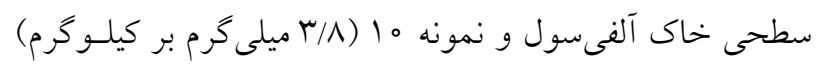

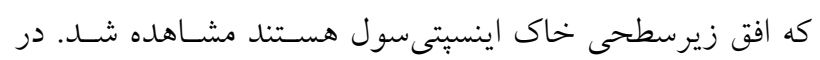

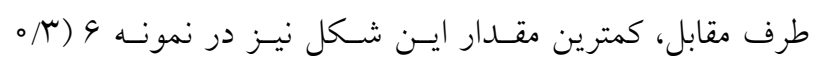

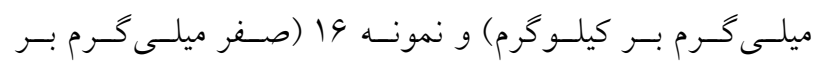

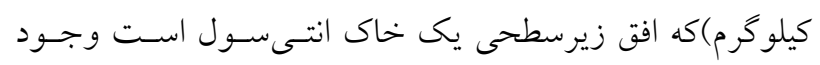

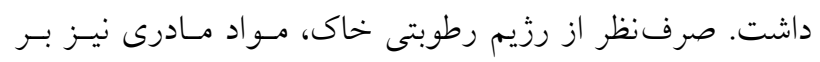

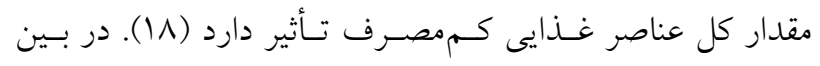

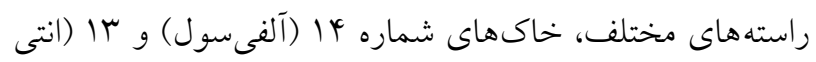

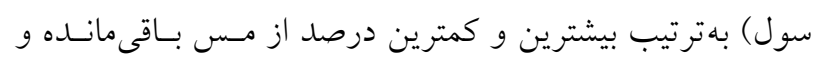

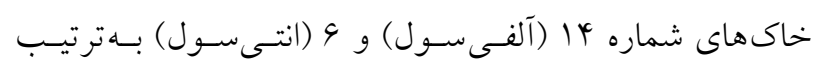

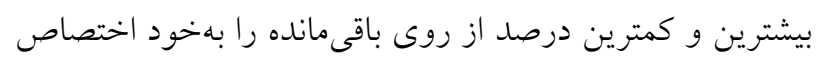

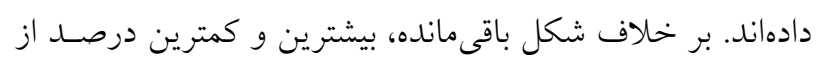
شكل كربناتى مس بهترتيب در راسته آلفىسول (خاك شـماره

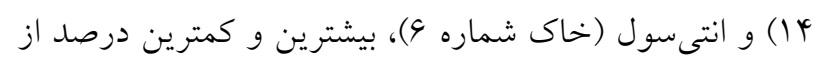

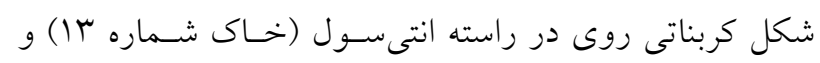

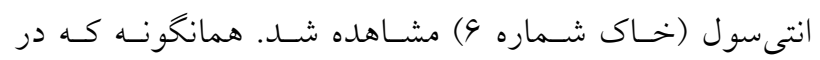

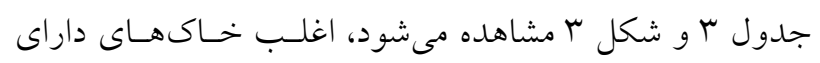

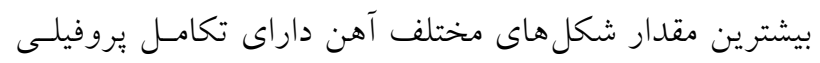

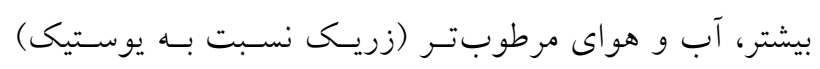

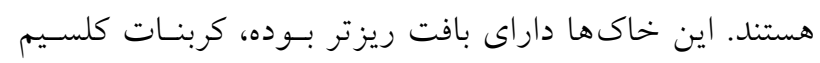

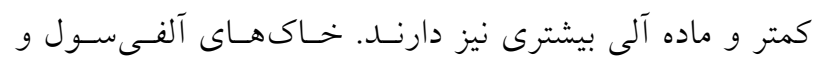

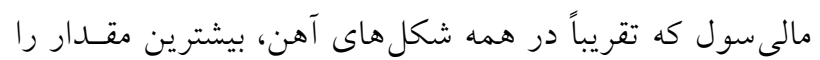

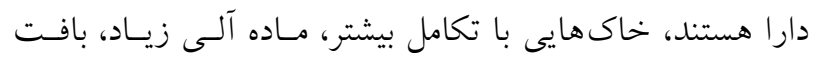

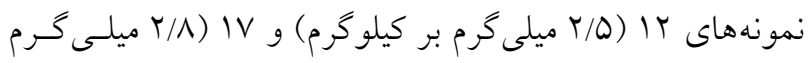

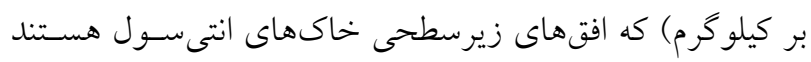
وجود داشتند. بررسى نسبى شكل هاى شيميايى هر راسته نشـان

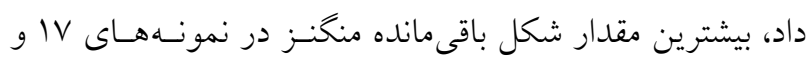

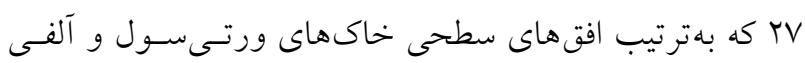

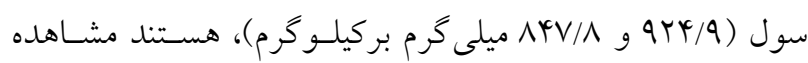

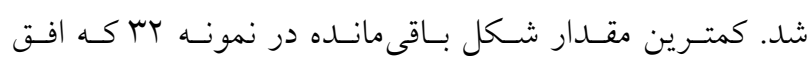

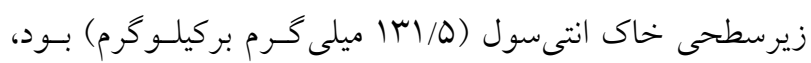
بهدست آمد. بيشترين مقدار شكل باقىمانده منكخنز در مناطق بـا بارنـدكى

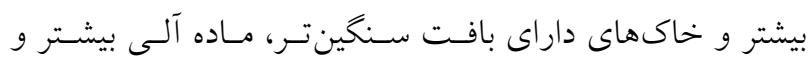

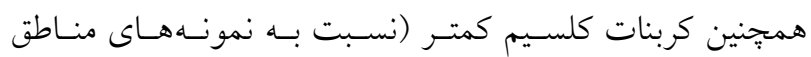
خشكتر)، مشاهده شد. صرفنظر از شكل زمين، مقــدار منگخـز

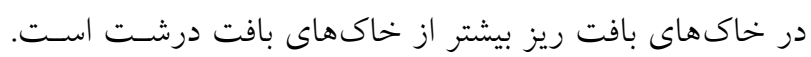

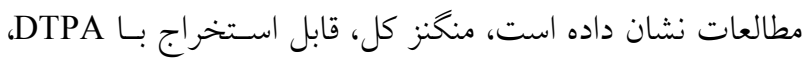

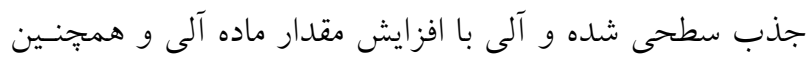

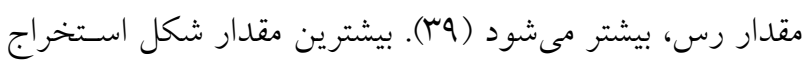

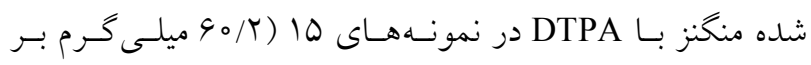

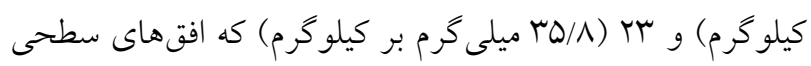

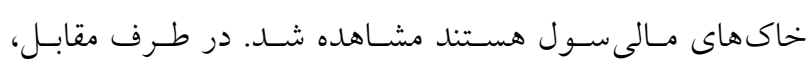

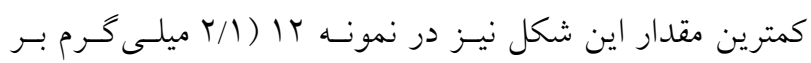

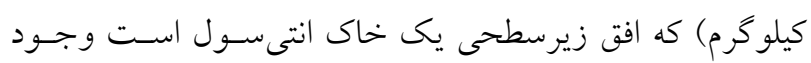

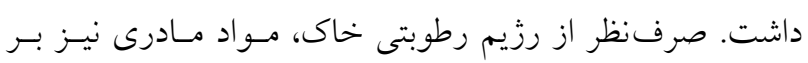

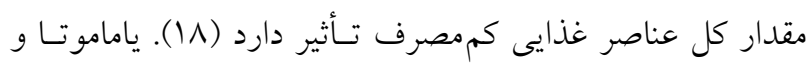

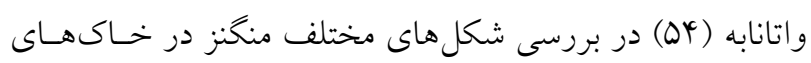

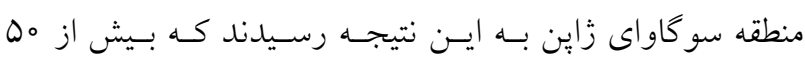

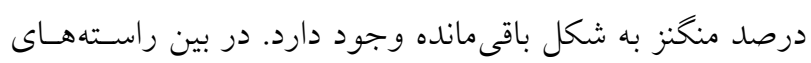

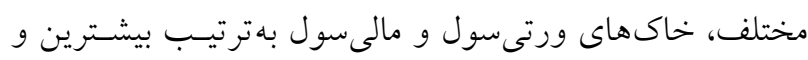

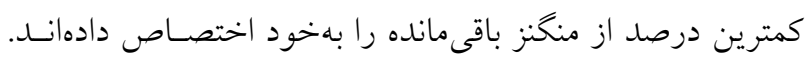

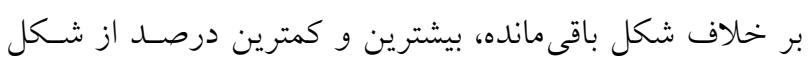

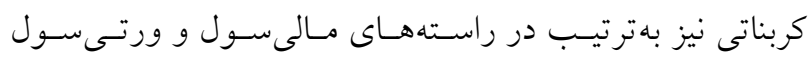

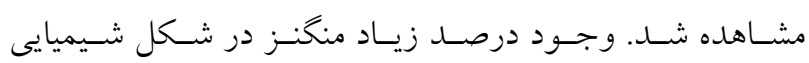



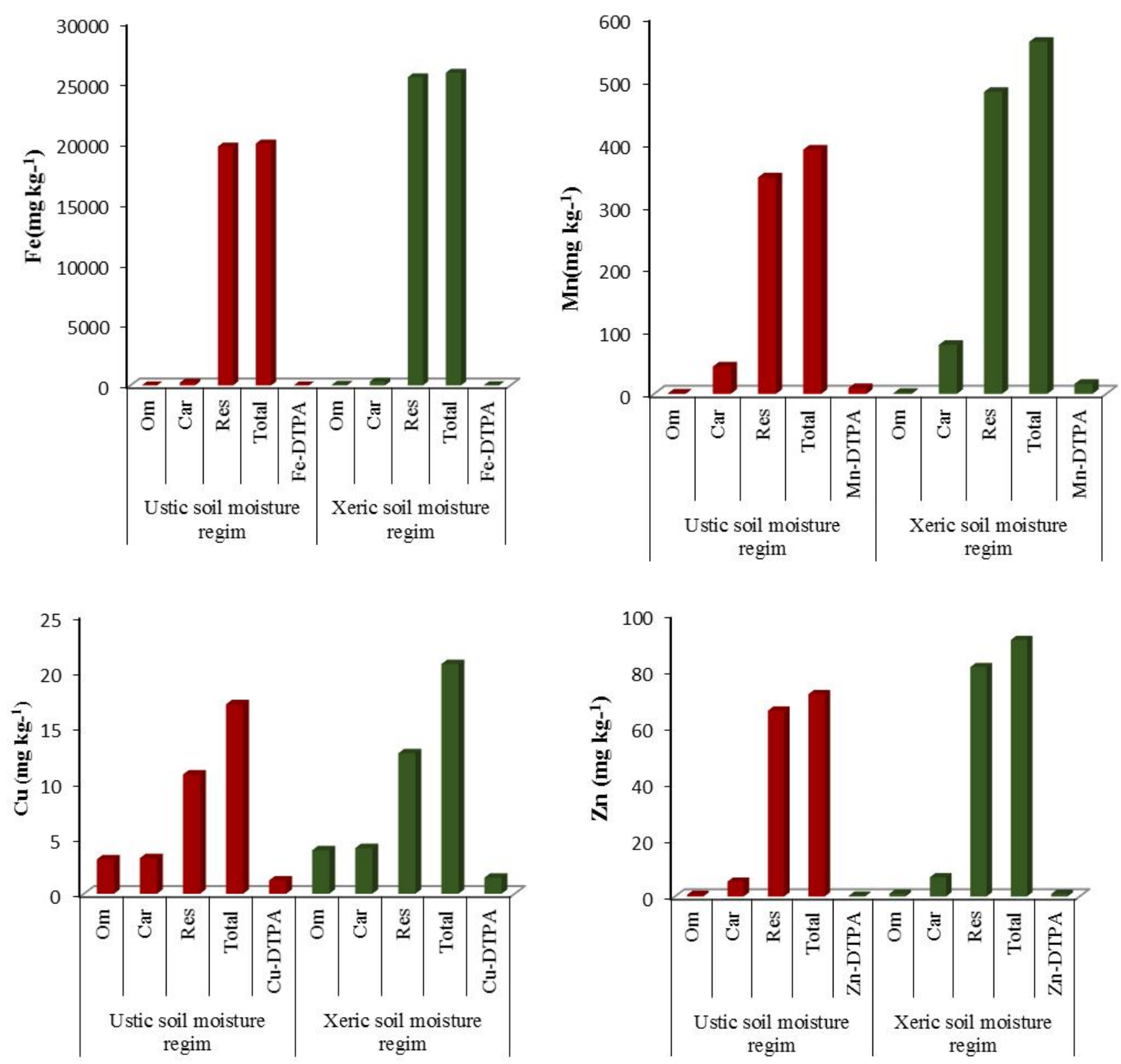

شكل r. توزيع شكلهاى مختلف عناصر در رزيمهاى رطوبتى موجود در منطقه مطالعاتى

شود، درحالى كه مقدار رس و ماده آلى كاهش مى يابد. بنسابر اين

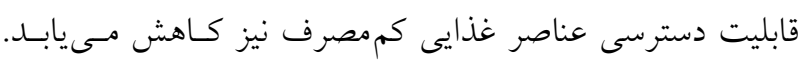

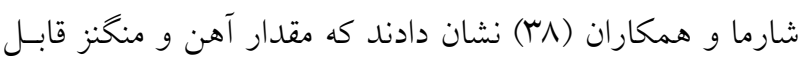

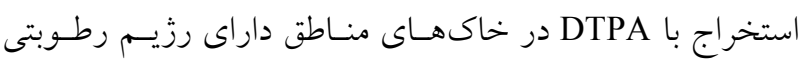

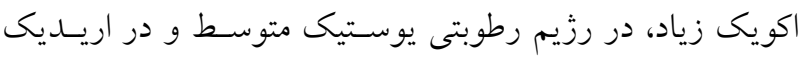

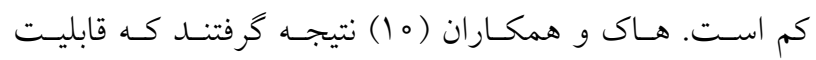

دسترسى عناصر غذايى كممصـرف در خـاكهـاى آلفسى هـول،
ريز و درصد كمتر كربنـات كلسـيم بـهدليـل شستشـوى بيشـتر

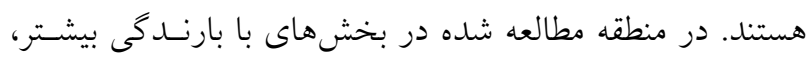

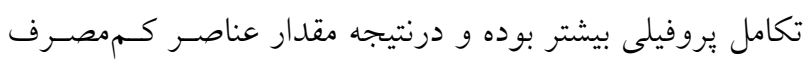

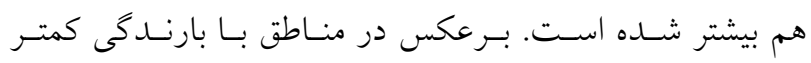

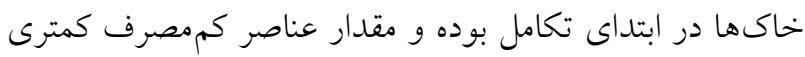

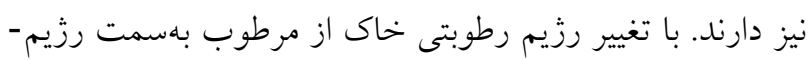

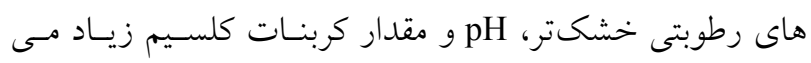


شكل آلى هر عنصر، شامل يونهاى جـذب سـطحى شـده،

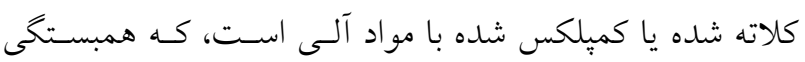

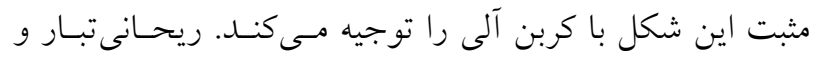

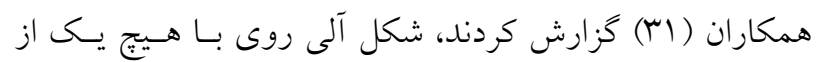

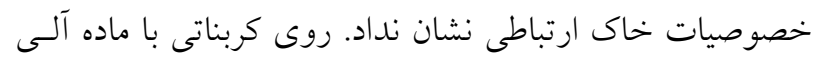

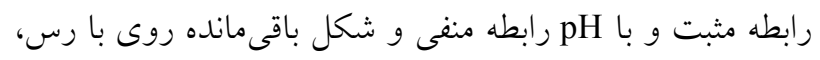

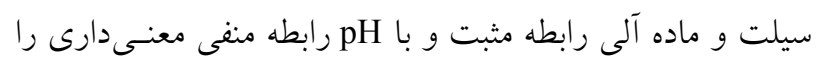

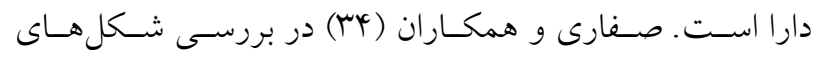

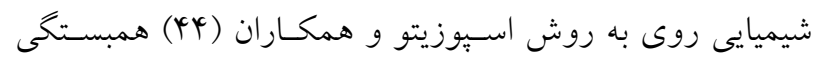

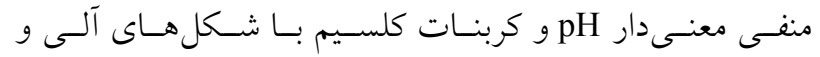

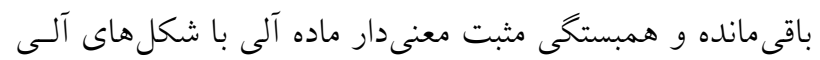
و باقىمانده و ظرفيت تبادل كاتيونى با سه شكل شسيميايى آلىى، كربناتى و باقى مانده را خزارش دادند.

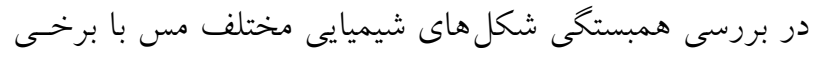

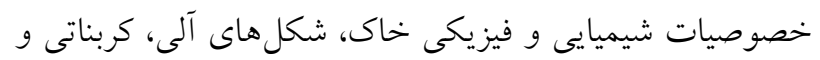

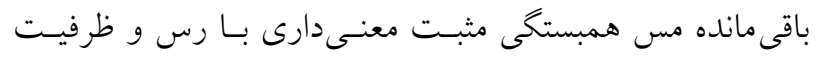

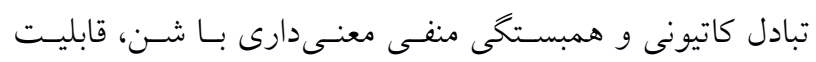

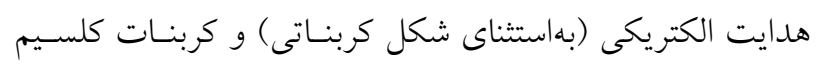

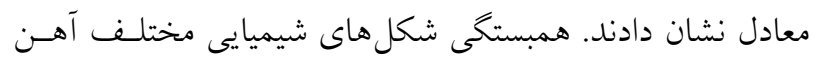
با برخى خصوصيات شيميايى و فيزيكى خاكهاى مورد مطالعه

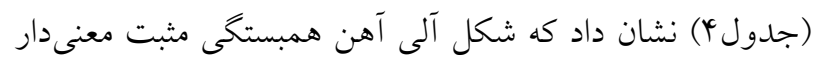

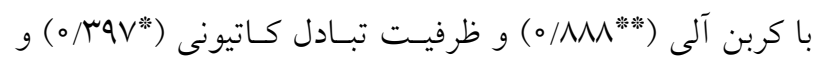

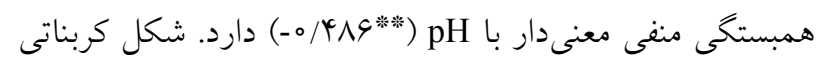

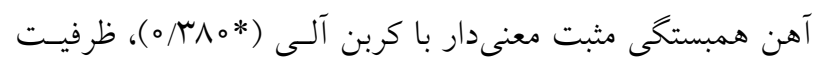

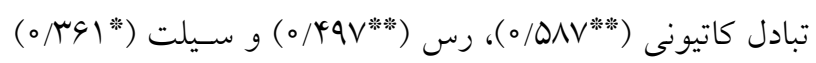

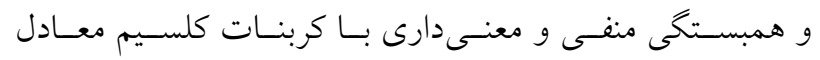

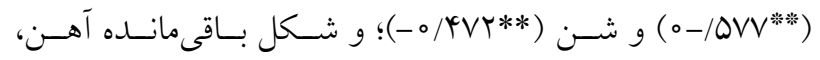

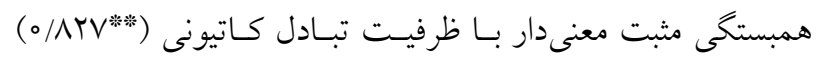

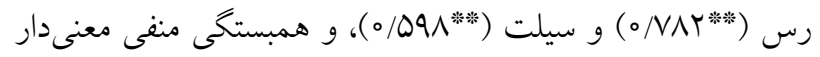

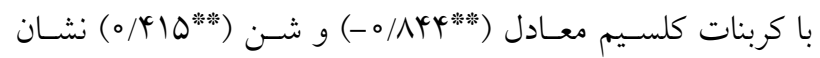
داده است. همجنين نتايج نشان از همبستكى مثبت معنى دار آهـن

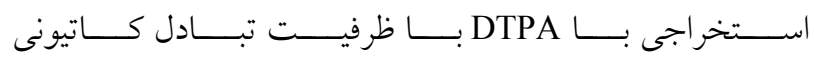

مالىسول و ورتى سول، بيشتر از خاكهاى اينسيتىسول، اريــى

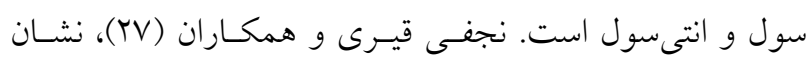

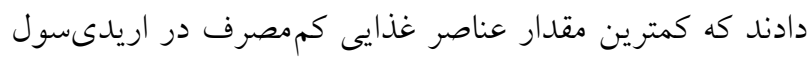
ها و خاكهاى داراى رزيم رطوبتى اريديك و يوستيك بود. آنها

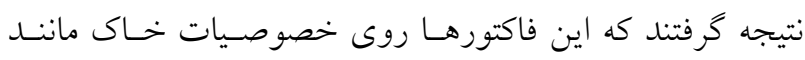

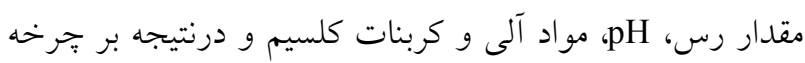
عناصر غذايى كممصرف و توزيع آنها مؤثر هستند. مقدار بيشستر

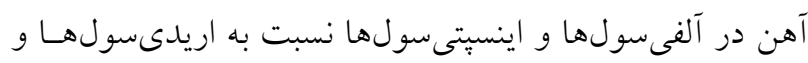

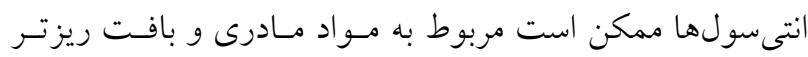

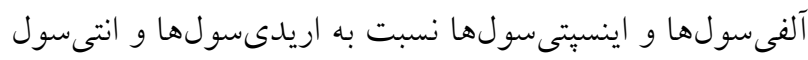

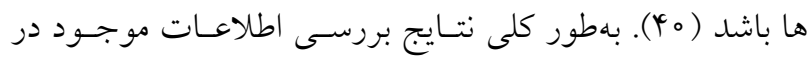

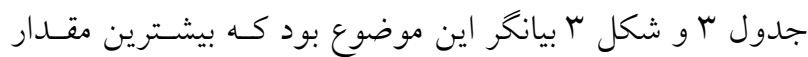
شكلهاى مختلف عناصر، در راستهاى خاك موجود در مناطق

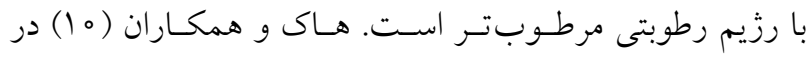
بررسى Yr خاك در سراسر اتيويى نشان دادند كه بيشترين ميزان

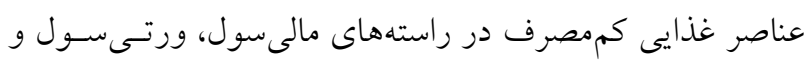
آلفى سول هستند.

همبستخى خصوصيات فيزيكى و شيميايى خاك با شكل هاى شيميايى عناصر

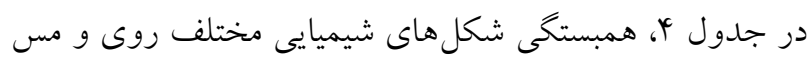

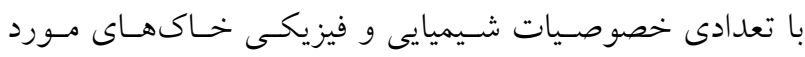

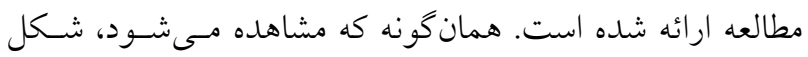

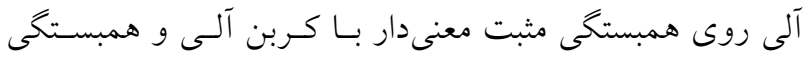

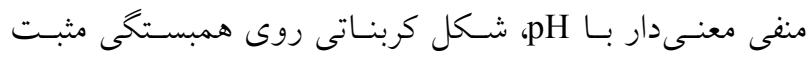

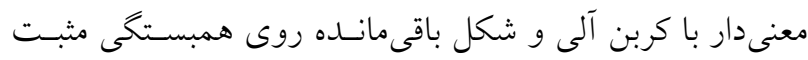

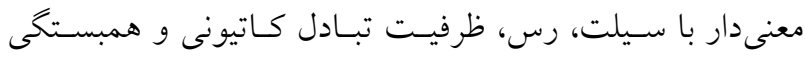
منفى معنى دار با شن و كربنات كلسيم معادل نشـان داده اسـت ريت.

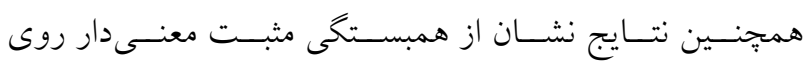

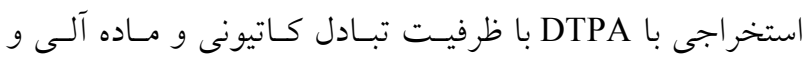
همبستخى منفى معنى دار با pH خاك دارد. 
جدول fا. همبستكى شكلهاى شيميايى روى، مس، منگنز و آهن با برخى خصوصيات فيزيكوشيميايى خاكهاى مورد مطالعه

\begin{tabular}{|c|c|c|c|c|c|c|c|c|c|c|c|c|}
\hline تبادل & كربن & آهك & بٌ هاش & رس & شن & پاليكورسكيت & كائولينيت & كوليت & كلريت & ايليت & اسمكتيت & شيميايى \\
\hline & & & & & روى & & & & & & & \\
\hline$\circ / 119$ & $\circ / 910 * *$ & $\% 44$ & $-0 / \mathcal{A}_{0}<*$ & $-0 / 1 Y q$ & o/rTa & r r/וס - & $-0 / 09$ & or &.$/ 199$ & $-0 / 09 \mu$ & $-0 / 09$ & آلى \\
\hline $0 / \pi \psi 1$ & $\circ / \Gamma \Delta V^{*}$ & $-0 / \pi \mid r$ & $-0 / 1 \times 4$ & $\circ \% r V$ & $-0 / 019$ & $-0 / r q V^{*}$ & $0 \% 49$ & $\circ / r \Delta V^{*}$ & $-0 / 0 \vee 9$ & $-0 / .90$ & $\circ / \Lambda \wedge \vee$ & كربناتى \\
\hline 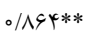 & D/rTQ & $-\circ / \Lambda 9 \Lambda^{* *}$ & $-0 / T+1$ & $\circ / V \uparrow q * *$ & $-\circ / V G 4 * *$ & -o/4ra* & $0 / T 19$ & $\circ / Q \wedge \circ * *$ & $-o / \mu \psi V *$ & $-0 / 19 V$ & $\circ / 900 * *$ & باقىمانده \\
\hline \multirow[t]{2}{*}{$\circ / \Delta \mathrm{rV}^{* * *}$} & $\circ / \Delta \wedge \digamma * *$ & $-0 / \mu_{\circ}$ & $-\circ / \Gamma \Delta Q^{*}$ & O/TYG & $-0 / / Y Y$ & $-\circ / 4 \circ \circ *$ & $0 \% 4$ & $\circ / 1 \Lambda$ & $-0 / 0 Y_{Y}$ & $-0 / Y \wedge 1$ &.$/ 190$ & استخراجى \\
\hline & & & & & مس & & & & & & & \\
\hline.$/ 99 \mathrm{~V} * *$ & $-0 / r 99$ & $-0 / 9 V_{0} * *$ & $-\circ / \wedge \Lambda$ & ./9VQ** & $-0 / 9 \circ 9 * *$ & - O/TYV & $\% \wedge \wedge$ & 。/DrY** & - & $-0 / \% 4$ & $0 / 401 *$ & آلى \\
\hline$\circ / 91 Q^{* * *}$ & $-0 / \mathrm{TNI}^{\prime}$ & - o/9Kr** & $-0 / M V Y$ & $\circ / 49 \Lambda^{* *}$ & -o/4ra* & -OMIT &.$/ 11 Y$ & $\circ / Q 1 \circ * *$ & $-0 / 111$ & $\% \%$ Kr & $0 / 490$ & كربناتى \\
\hline$\circ / 0.1 * *$ & $-0 / 190$ & - o/Qra** & $-0 / . r V$ & $\circ / \mathrm{V} \cdot q^{*} *$ & $-\circ / \Delta V / * *$ & $-0 / T G 4$ & $0 / T_{01}$ & $\circ / 410 *$ & $-\circ / \Gamma V Q *$ & $-0 /$ rqT & $\circ / \pi I F$ & باقى مانده \\
\hline \multirow[t]{2}{*}{.$/ 994 * *$} & $-0 / 499$ & $-o / N Y Y^{* *}$ & $-0 / M M$ &.$/ 909 * *$ & & - & $\%$ \% & $\circ / \Delta \& \Delta * *$ & $-0 / 19$ & $-0 / 0 Y_{9}$ & $\circ / 49 \mu * *$ & استخراجى \\
\hline & & & & & آهن & & & & & & & \\
\hline$\circ / r q V^{* * *}$ & 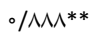 & $-\% \% V r$ & - $/ \nVdash \wedge ฯ^{* * *}$ & 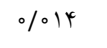 & $\% 40$ & $-0 / 1 r \wedge$ & $\%$ ove & $0 / 04$ & $\% 1090$ & $0 / 019$ & 。 & آلى \\
\hline$\circ / \Delta \wedge V^{* *}$ & $\circ /$ 八。* $^{\prime}$ & $-\circ / \Delta V V^{* *}$ & $-0 / r \mid r$ & $\circ / 4 ৭ V^{* *}$ & $-\circ / \mathcal{A Y} r^{* *}$ & $-0 / 4 \varphi_{0} *$ & $\circ / \pi \circ 9$ & $0 / 494 * *$ & $-0 / T r$ & $-0 / 09 r$ & $0 / f<4 *$ & كربناتى \\
\hline ०/AYV** &.$/ 1 V I$ & -o/AkF** & $-0 / 109$ & -/VAr & $-0 / \wedge 1 \circ * *$ & $-0 / 4 \psi \mid *$ & $0 / 1 r a$ & $\circ / 9 \circ 9 * *$ & $-\circ / \uparrow \Delta \Delta^{* * *}$ & $-0 / 199$ & o/qrq** & باقىمانده \\
\hline \multirow[t]{2}{*}{$\circ / 990 * *$} & - $/ 4 a r * *$ & $-\circ / \Delta \Delta r^{* * *}$ & $-0 / T V V$ & $0 / 419 *$ & & $-o / r V \mid * *$ & $\% \% V V$ & 。/ヘヘץ** & - O/NFY & $-0 / 0 \mathrm{VI}$ & $\circ / 4 r \Delta *$ & استخراجى \\
\hline & & & & & منكنز & & & & & & & \\
\hline o/KrY** & $\circ / 9 \circ * * *$ & $-0 / 0 \vee 9$ & - o/DrY** & $\% 011$ & $-0 / 044$ & $-0 / Y 19$ &.$/ 111$ & $-0 / 011$ & $\% / \wedge \wedge$ & $\% \circ 00$ & $-0 / 01 r$ & آلى \\
\hline.$/ 0.4 * *$ & o/rGr** & $-o / \& r y * *$ & $-0 / / 19$ & 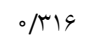 & $-0 / Y 1 Q$ & - & $\% \diamond \Delta V$ & $\circ / \Delta \cdot \vee * *$ & $-0 / 1 M$ & $-\circ \% \circ \mathrm{V}$ & $\% \Delta$ & كربناتى \\
\hline.$/ 944 * *$ & $\% 1 r$ & $-\circ / V 9 \mid * *$ & $-0 / 00 r$ & $\circ / \Delta \wedge \vee^{* *}$ & $-0 / 9 \mu \mu * * *$ & $-0 / V_{0} *$ & $\circ / T M$ & $\circ / \uparrow \Delta Q * *$ & $-\circ / 4 \circ \wedge^{*}$ & $-0 / / Q V$ & o/Qr I** & باقى مانده \\
\hline$\circ / \Delta Q 4 * *$ & ०/AYI** & $-0 / K 4 \wedge$ & $-\circ / \Delta \wedge \varphi^{* * *}$ & $\circ / \circ \wedge$ & $-0 / T r V$ & $-\circ / \pi \Delta \circ *$ & $\% \Delta \Delta \Delta$ &.$/ 191$ & $-0 / \% \psi v$ & \%००r & \%०ᄉr & استخراجى \\
\hline
\end{tabular}

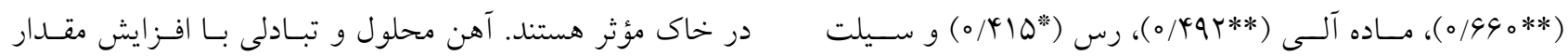

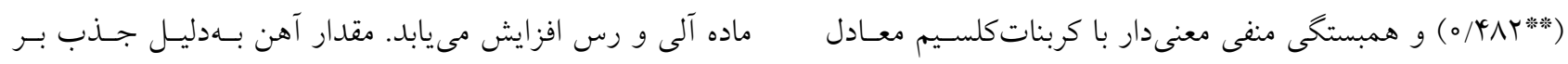

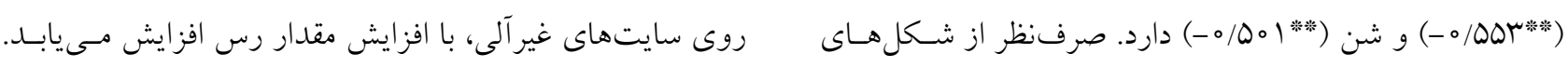

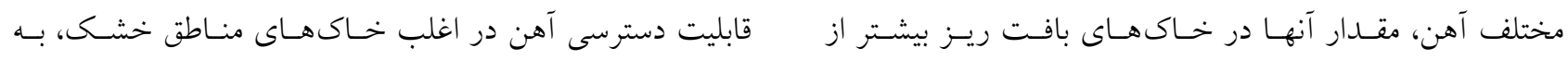

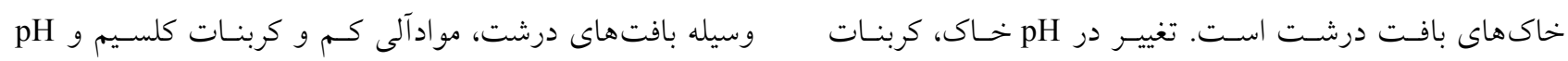
كلسيم، مواد آلى و بافت خاك در توزيع شكل هاى مختلف آهن زياد، محدود مىشود. ارتباط مستقيم بين مقـدار رس بـاـ مقـادير 


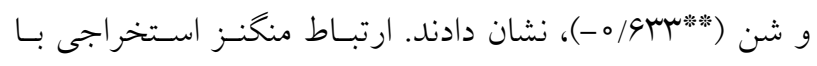

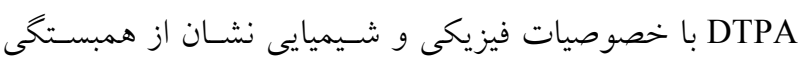

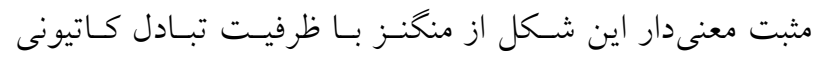

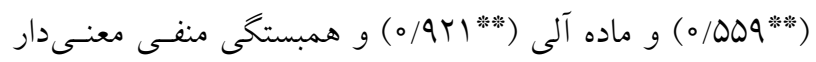
با pH بيشتر از خاكهاى بافت درشت است. منگُنز كل، قابل استخراج

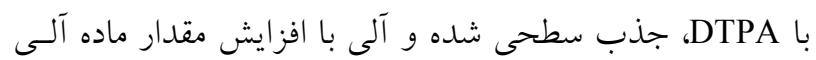
و همبنين مقدار رس، بيشتر مى شود (وس). يـاداو (UT) مشـاهده

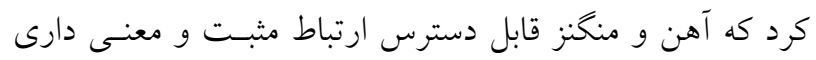
با كربن آلى و ارتباط منفى و معنىدارى با pH و مقدار كربنـات

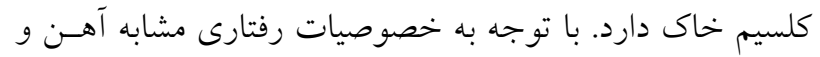
منكنز در خاك، دلايل ارتبـاط خصوصسيات خـاك و منخخنز در

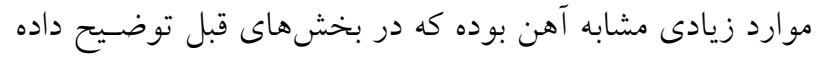

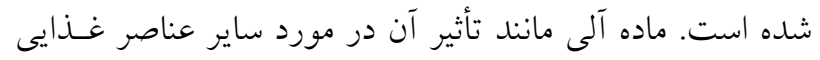

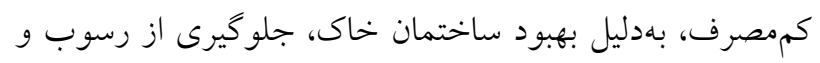

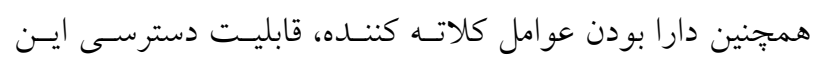

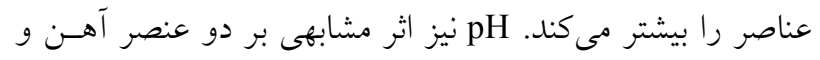

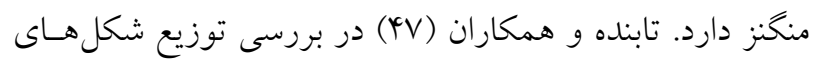

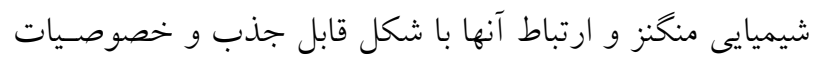

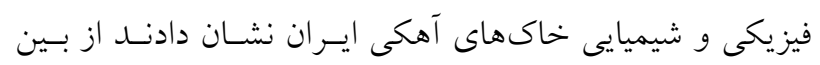

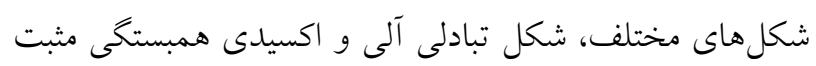

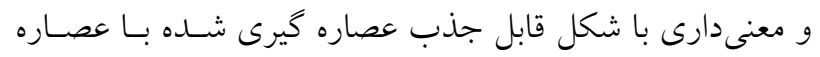

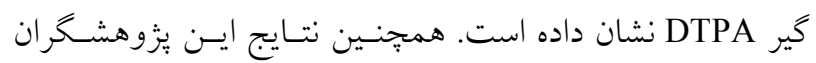

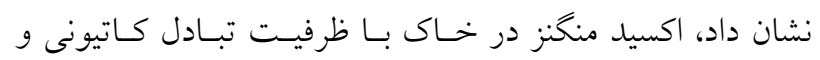
درصد رس هبستكى مثبت و با درصــ كربنـات كلسيم معـادل همبستخى منفى معنى دار نشان دارد.

\section{همبستخى كانىهاى رسى خاك با شكلهاى شيميايى عناصر} همان كونه كه در جدول \& مشاهده مىشود، شكل كربنساتى روى

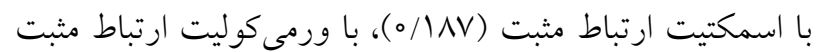

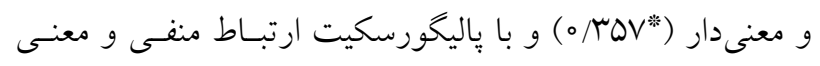

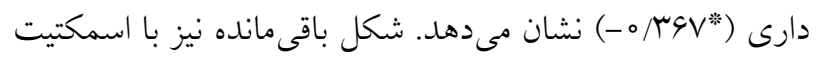

آهن كـل در مطالعـات كشــاورزى و همكــاران (19) در شـمال

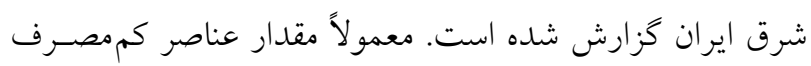

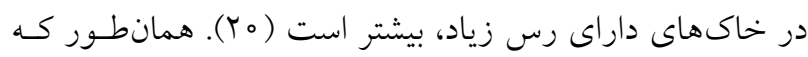

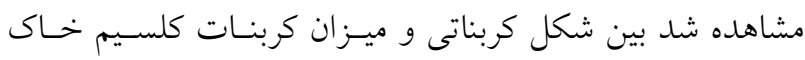

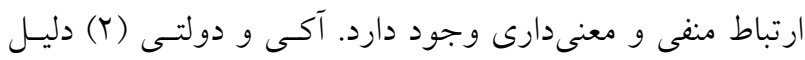

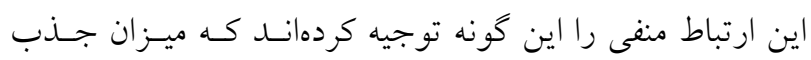

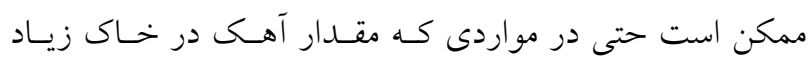

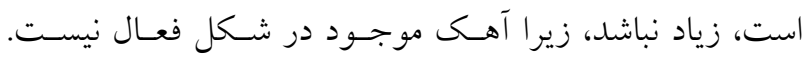

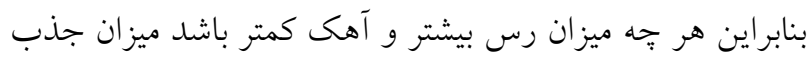
نيز بيشتر مىشود. در خاكهاى مورد مطالعه، بين ميـزان رس و كربنات كلسيم خاك ارتباط منفى و معنسىدارى وجـود دارد. بـا لـا افزايش ظرفيت تبادل كاتيونى بهدليل افزايش سايتهاى تبـادلى نقلى

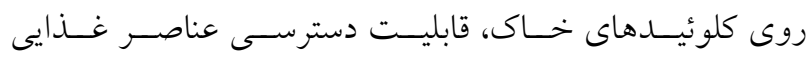

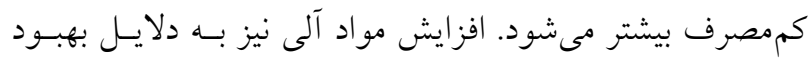

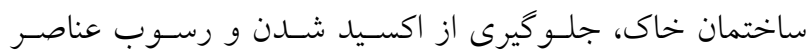

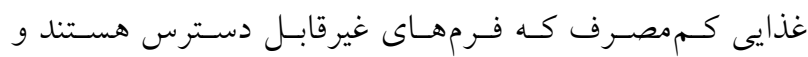

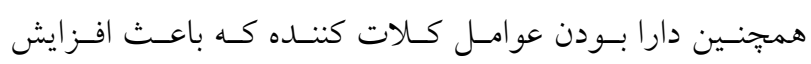

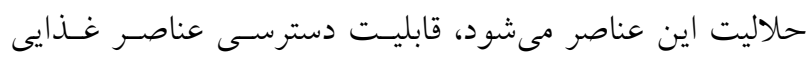

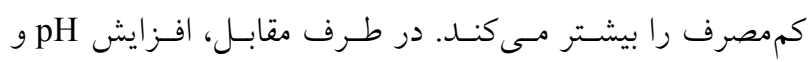

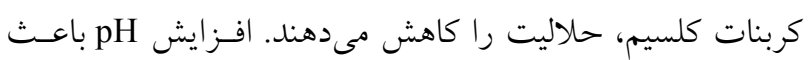

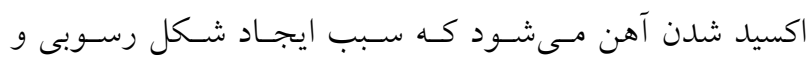

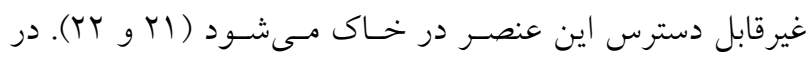

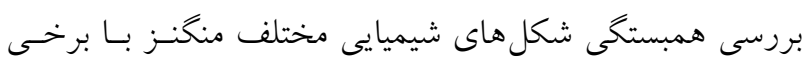

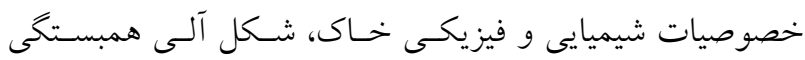

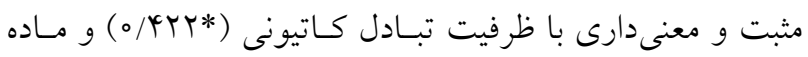

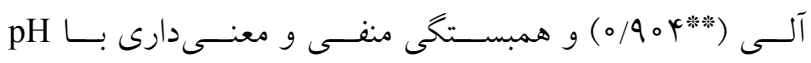
(ناد)

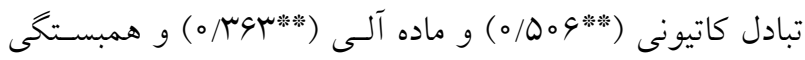

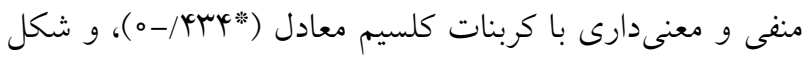

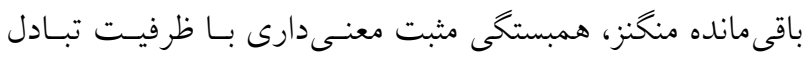

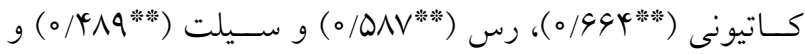

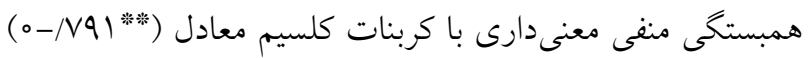


در مناطقى كه كربنات كلسيم بيشتر است رس كمتر بوده و كانى

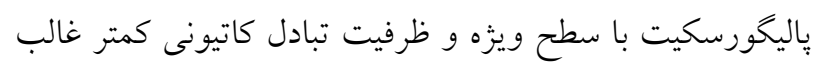

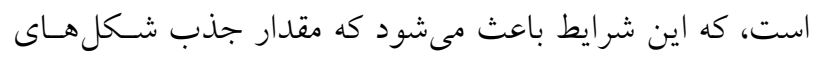

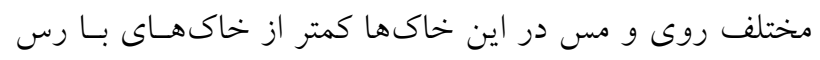

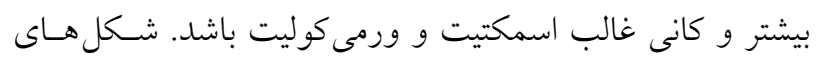

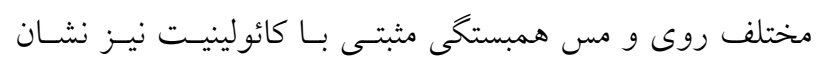

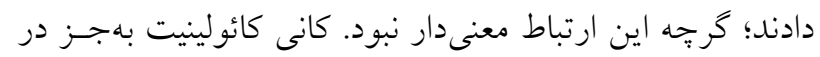

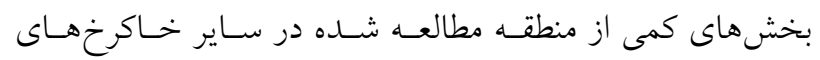

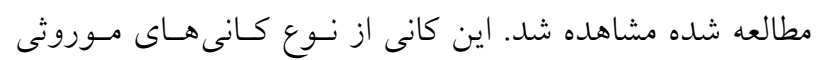

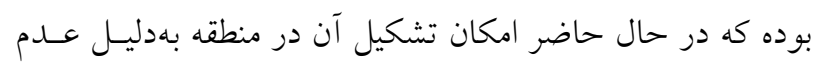
وجود شرايط لازم ممكن نيست. اين كانى داراى بار وابسته بـهـ

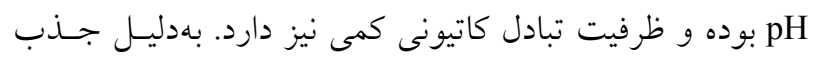

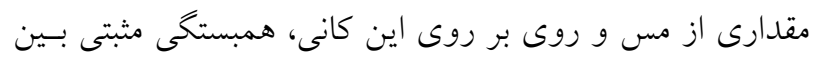

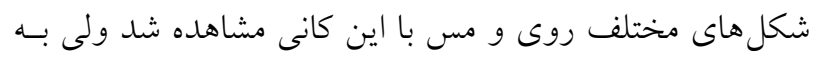

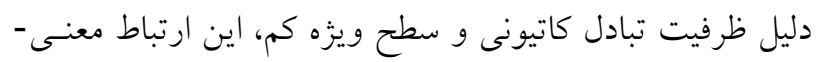

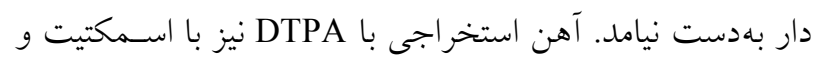

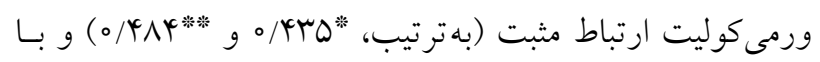

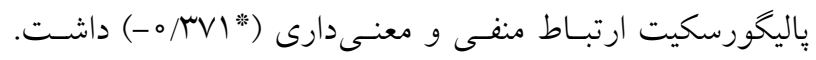

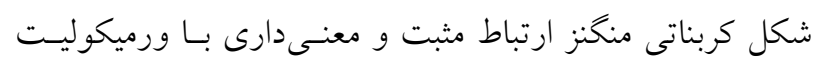

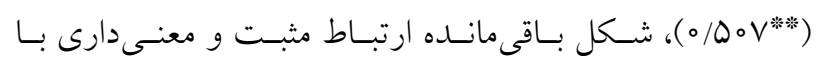

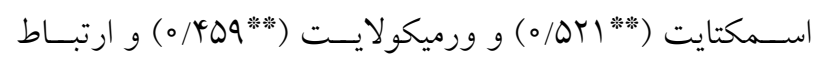

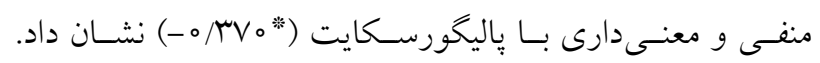

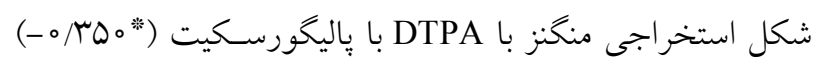

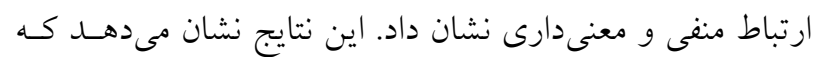

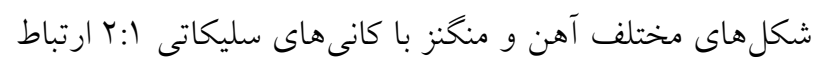

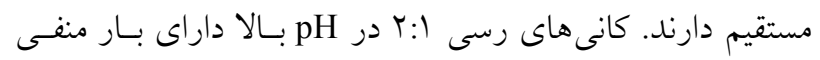

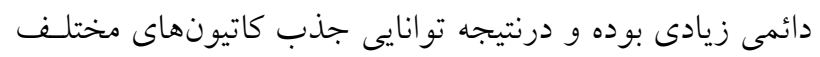

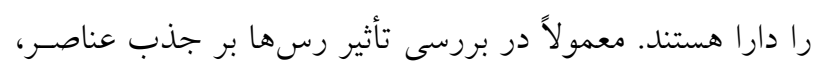

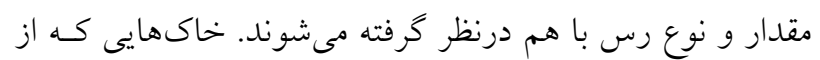

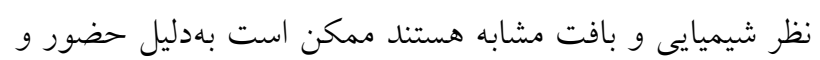

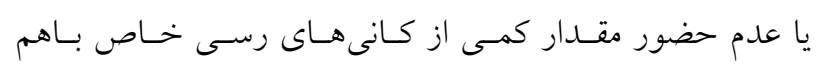
متفاوت باشند. براى مثال اسمكتايتها تبادل كنندهاى كـاتيونى لئى

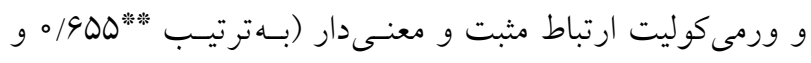

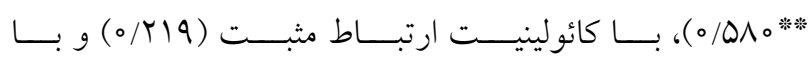

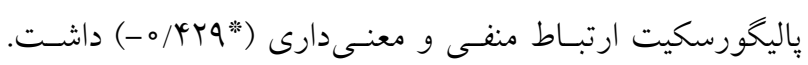

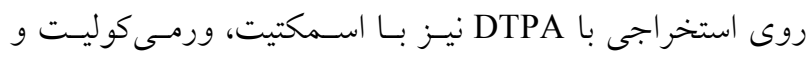

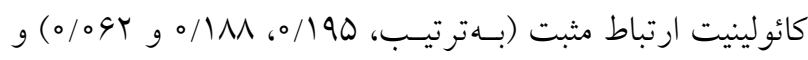

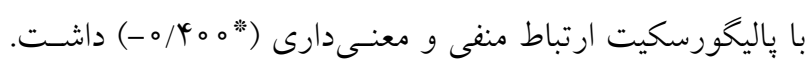

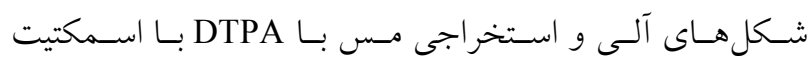

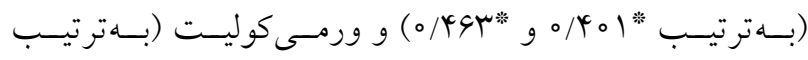

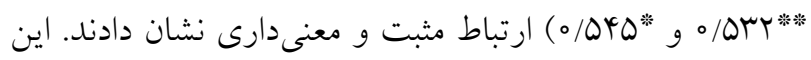

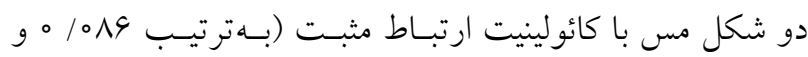

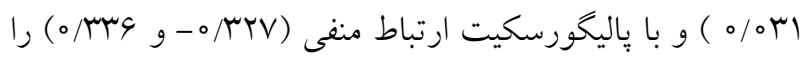

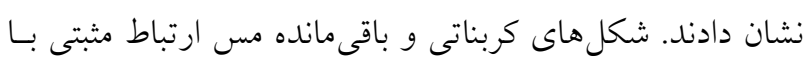

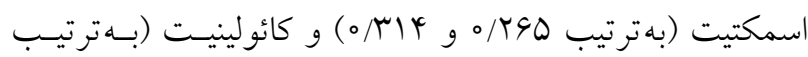

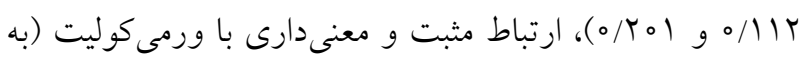

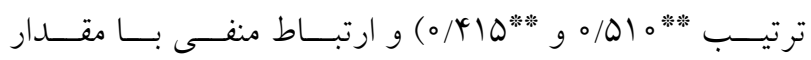

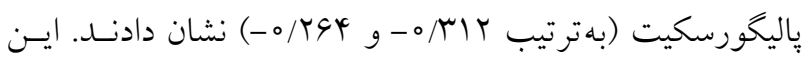

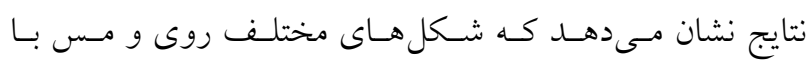

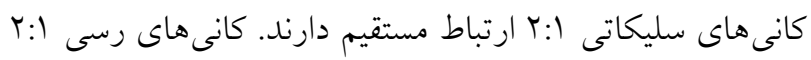

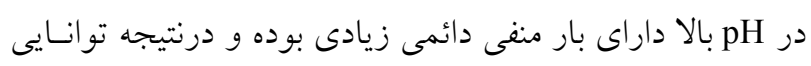
جذب كاتيونهاى مختلف را دارا هستند. طبق مطالعـات سـيبوز

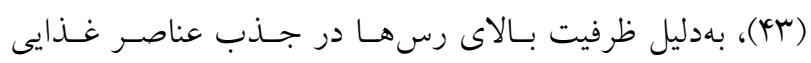
كممصرف مثل روى و مس، زيستفراهمى آنها با افزايش مقدار

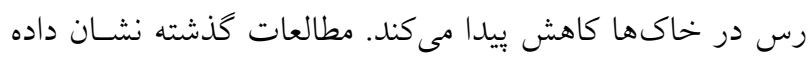

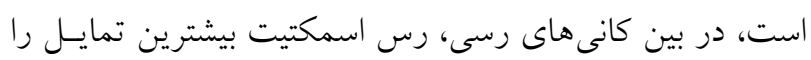

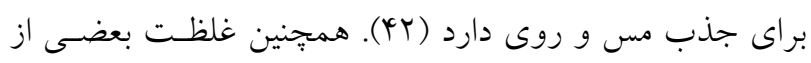

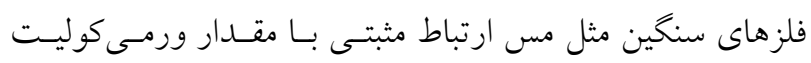

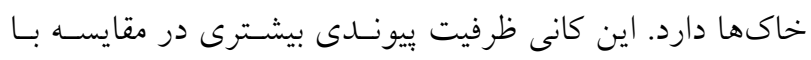

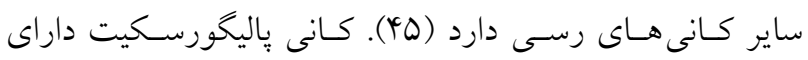

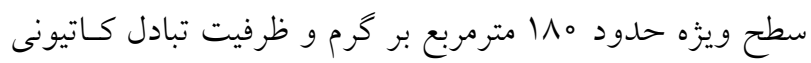

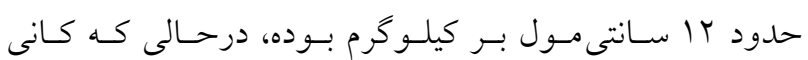

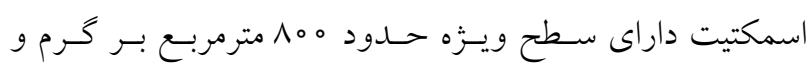

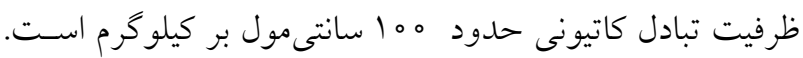




$$
\begin{aligned}
& \text { كه كربنات كلسيم بيشتر بـوده اسـت، ميـزان رس كمتـر بـوده و } \\
& \text { بسيار قوى هستند حضور آنها مىتواند تا حد زيادى بـر تحـرى } \\
& \text { كانى پاليكورسكيت با سطح ويزه و ظرفيت تبادل كاتيونى كمتسر }
\end{aligned}
$$

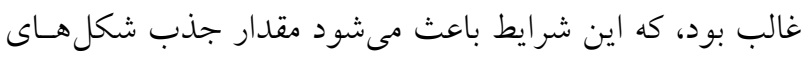

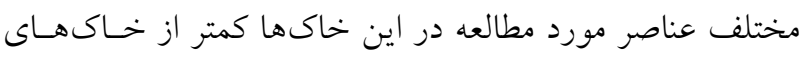

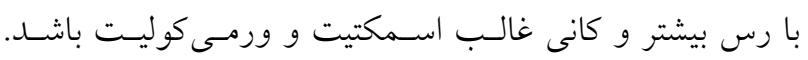

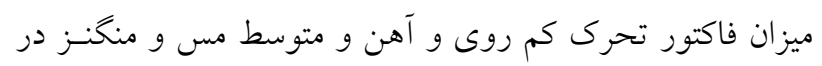

$$
\begin{aligned}
& \text { بيشتر خاكهاى مورد مطالعه نشان از رفتار متفاوت اين عناصـر } \\
& \text { در خاكهاى آهكى منطقه دارد. بررسى هاى تحقيق حاضر نشان مان }
\end{aligned}
$$

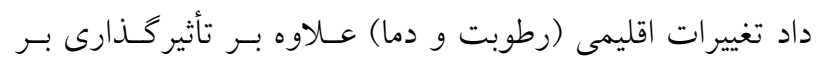

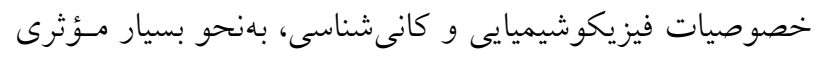

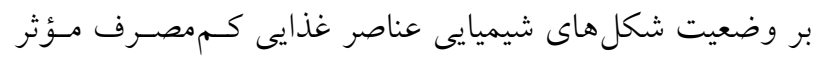

$$
\begin{aligned}
& \text { است. }
\end{aligned}
$$

\section{منابع مورد استفاده}

1. Abollino, O., A. Giacomino, M. Malandrino, E. Menthasi, M. Aceto and R. Barberis. 2006. Assessment of metal availability in contaminated soil by sequential extraction. Water Air Soil Pollution 137: 315.

2. Akay, A. and B. Doulati. 2012. The effect of soil properties on $\mathrm{Zn}$ adsorption. Journal of International Environmental Application and Science 7(1): 151-160.

3. Alavi, H., M. Barani Motlagh and E. Dordipour. 2013. Determination of chemical forms of copper and their relationships with plant responses and soil properties in some soils of Golestan Province. Journal of Water and Soil Conservation. 19(3): 43-62. (In Farsi).

4. Azadi, A. and M. Baghernejad. 2015. Study of morphological and mineralogical properties, potassium and phosphorus status in three soil toposequences of Fars province, Ph.D. dissertation in Soil Science, College of Agriculture Shiraz University. Iran.

5. Bell, R. W. and B. Dell. 2008. Micronutrients for Sustainable Food, Feed, Fibre and Bioenergy Production. International Fertilizer Industry Association (IFA), Paris, France.

6. Buoyoucos, G. J. 1962. Hydrometer method for marking particle size analysis of soil. Agronomy. Journal 54: 46614665.

7. Connolly E. L., N. Campbell, N. Grotz, C. L. Prichard and M. L. Guerinot. 2003. Overexpression of the FRO iron reductase confers tolerance to growth on low iron and uncovers post-transcriptional control. Plant Physiolgy 133(3):1102-1110.

8. Elgabaly, M. M. 1950. Mechanism of zinc fixation by colloidal clays and related minerals. Soil Science 69(3): 167174.

9. Ginder-Vogel, M. and D. L Sparks. 2010. The impacts of X-ray absorption spectroscopy on understanding soil processes and reaction mechanisms. Developments in Soil Science 34: 1-26.

10. Haque, I., N Z. Lupwayi and T. Tadesse. 2000. Soil micronutrient contents and relation to other soil properties in Ethiopia. Communications in Soil Science and Plant Analysis 31: 2751-2762.

11. Harter, R. D. 1991. Micronutrient adsorption-desorption reactions in soils. PP. 59-87. In: Mortvedt J. J., F. R. Cox, L. H. Shuman and R. H. Welch (Eds.), Micronutrients in Agriculture. SSSA, Madison, WI.

12. Havlin, J. L., S. L. Tisdale, W. L. Nelson and J. D Beaton. 2016. Soil Fertility and Fertilizers. Pearson Education India.

13. Helios Rybicka, E., W. Calmano and A. Breeger. 1995. Heavy metals sorption/desorption on competing clay minerals; an experimental study. Applied Clay Science 9(5): 369-381. 
14. Jalali, M. and Z. V. Khanlari. 2007. Redistribution of fractions of zinc, cadmium, nickel, copper, and lead in contaminated calcareous soils treated with EDTA. Archives of Environmental Contamination and Toxicology 53(4): 519-532.

15. Jeong, G. Y., S. Hillier and R. A. Kemp. 2011. Changes in mineralogy of loess-paleosol sections across the Chinese Loess Plateau. Quaternary Research 75: 245-255.

16. Johns, W. D., R. E. Grim and F. Bradley. 1954. Quantitative estimations of clay minerals by diffraction methods. Journal of Sedimentary Research 24(4): 242-251.

17. Kamangar, O., A. Reyhanitabar and S. Oustan. 2017. Determination of copper fractions and their relations with soil properties in some soils of East Azerbaijan province. Water and Soil Science 27(4): 63-74. (In Farsi).

18. Katyal, J. C. and B. D Sharma. 1991. DTPA-extractable and total Zn, Cu, Mn, and Fe in Indian soils and their association with some soil properties. Geoderma 49: 165-179.

19. Keshavarzi, A., V. Kumar, E. L. Bottega and J. Rodrigo-Comino. 2019. Determining land management zones using pedo-geomorphological factors in potential degraded regions to achieve land degradation neutrality. Land 8(6): 92.

20. Keshavarzi, A. and V. Kumar. 2018. Ecological risk assessment and source apportionment of heavy metal contamination in agricultural soils of Northeastern Iran. International Journal of Environmental Health Research 29(5): 544-560.

21. Khormali, F. and M. Kehl. 2011. Micromorphology and development of loess-derived surface and buried soils along a precipitation gradient in Northern Iran. Quaternary International 234: 109-123.

22. Kumar, M. and A. Babel. 2011. Available micronutrient status and their relationship with soil properties of Jhunjhunu tehsil, District Jhunjhunu, Rajasthan, India. Journal of Agricultural Science 3(2): 97-106.

23. Loeppert, R. H. and D. L. Suarez. 1996. Carbonate and gypsum. PP. 437-474. In: Sparks D. L. (Eds.), Methods of Soil Analysis, SSSA Book Series, Part 3, Madison, WI.

24. Mathur, B. S., S. K. Singh, B. P. Gupta and P. Kumar. 1998. Studies on some forms of iron and aluminium and their release in relation to acidity of Chotanagpur soils. Journal of the Indian Society of Soil Science 46(3): 456-458.

25. Mitchell, R. L.1964. Trace elements in soils. PP. 320-368. In: Bear, F. E. (Eds.), Chemistry of Soil. Oxford \& IBH, Calcutta.

26. Nael, M., H. Khademi, A. Jalalian, R Schulin, M. Kalbasi and F. Sotohian. 2009. Effect of geo-pedological conditions on the distribution and chemical speciation of selected trace elements in forest soils of western Alborz, Iran. Geoderma 152(1-2): 157-170.

27. Najafi-Ghiri, M., R. Ghasemi-Fasaei and E. Farrokhnejad. 2013. Factors affecting micronutrient availability in calcareous soils of Southern Iran. Arid Land Research and Management 27(3): 203-215.

28. Nelson, D. W. and L. E. Sommers. 1996. Total carbon, organic carbon, and organic matter. PP. 961-1010. Methods of Soil Analysis part 3-Chemical Methods, (Methodsofsoilan3).

29. Németh T., I. Mohai and M. Tóth. 2005. Adsorption of copper and zinc ions on various montmorillonites: an XRD study. Acta Mineralogica-Petrographica 46: 29-36.

30. Ramos, L., L. M. Hernandez and M. J. Gonzalez.1994. Sequential fractionation of copper, lead, cadmium and zinc in soils from or near Donana National Park. Journal of Environmental Quality 23(1): 50-57.

31. Reyhani Tabar, A., N. A. Karimian, M. Muazardalan, G. R. Savaghebi and M. R. Ghannadha. 2006. Zinc fractions of selected calcareous soils of Tehran province and their relationships with soil characteristics. Journal of Science and Technology of Agriculture and Natural Resources 10(3): 125-136. (In Farsi).

32. Richards, L. A. 1954. Diagnosis and Improvement of Saline and Alkaline Soils. United States Department of Agriculture Handbook No. 60. United States Government Printing Office, Washington DC.

33. Saffari, M., N. Karimian, A. Ronaghi, J. Yasrebi and R. Ghasemi-Fasaei. 2016. Stabilization of lead as affected by various amendments and incubation time in a calcareous soil. Archives of Agronomy and Soil Science 62(3): 317337.

34. Saffari, M., J. Yasrebi, N. Karimian. and X. Shan. 2009. Evaluation of three sequential extraction methods for fractionation of zinc in calcareous and acidic soils. Research Journal of Biological Sciences 4(7): 848-857.

35. Salbu, B. and T. Krekling. 1998. Characterisation of radioactive particles in the environment. Analyst 123(5): 843850 .

36. Shakeri, S., S. A. Abtahi, N. A. Karimian, M. Baghernejad and H. R. Owliaie. 2015. Kinetics of nonexchangeable potassium release in surface and subsurface horizons of predominant soil series in Kohgilouye-va-Boyerahmad Province. Journal of Water and Soil Science 19(73): 301-319. (In Farsi).

37. Shakeri, S. and S. A. Abtahi. 2018. Potassium forms in calcareous soils as affected by clay minerals and soil development in Kohgiluyeh and Boyer-Ahmad Province, Southwest Iran. Journal of Arid Land 10(2): 217-232.

38. Sharma, B. D., S. S. Mukhopadhyay, P. S. Sidhu and J. C. Katyal. 2000. Pedospheric attri- butes in distribution of total and DTPA-extractable $\mathrm{Zn}, \mathrm{Cu}, \mathrm{Mn}$ and Fe in Indo-Gangetic plains. Geoderma 96: 131-151. 
39. Sharma, B. D., Seth. Anubhuti, S. Saini Rajinder and D. Salwinder Singh. 2011 Distribution of different forms of $\mathrm{Mn}$ and their association with soil properties in arid zone soils of Punjab, India, Archives of Agronomy and Soil Science 57(1): 15-26.

40. Sharma, B. D., R. K. Harsh-Arora and V. K. Nayyar. 2004. Relationships between soil characteristics and total and DTPA-extractable micronutrients in Inceptisols of Punjab. Communications in Soil Science and Plant Analysis 35: 799-818.

41. Sheldon, N. D. and N. J. Tabor. 2009. Quantitative paleoenvironmental and paleoclimatic reconstruction using paleosols. Earth Science Reviews 95: 1-52.

42. Shukla, L. M. 2002. Sorption of Zn and Cd on soil clays. Agrochemical 44: 101-106.

43. Sipos, P. 2003. Distribution of $\mathrm{Cu}, \mathrm{Ni}, \mathrm{Pb}$ and $\mathrm{Zn}$ in natural brown forest soil profiles from the Cserhat $\mathrm{Mts}$., $\mathrm{Ne}$ Hungary. Acta Mineralogical-Petrografica 44: 43-50.

44. Sposito, G., L. J. Lund and A. C. Chang. 1982. Trace metal chemistry in arid-zone field soils amended with sewage sludge: I. fractionation of $\mathrm{Ni}, \mathrm{Cu}, \mathrm{Zn}, \mathrm{Cd}$, and $\mathrm{Pb}$ in solid phases 1. Soil Science Society of America Journal 46(2): 260-264.

45. Sultan, K. 2006. Clay mineralogy of central Victorian (creswick) soils: clay mineral contents as a possible tool of environmental indicator. Soil and Sediment Contamination 15(4): 339-356.

46. Sumner, M. E. and W. P. Miller. 1996. Cation exchange capacity and exchange coefficients. PP. 1201- 1229, Methods of Soil Analysis Part 3 - Chemical Methods, (methodsofsoilan3).

47. Tabande, L., M. R. Bakhshi and N. A. Karimian. 2013. Evaluation of the relationships between Cu chemical forms and $\mathrm{Cu}$ uptake by Soybean in several calcareous soils in Fars Province. Journal of Soil Management and Sustainable Production 3(1): 183-198. (In Farsi).

48. Taylor, G. and R. A. Eggleton. 2001. Regolith Geology and Geomorphology. John Wiley \& Sons, NY.

49. Torri, S. I. and R. S. Lavado. 2008. Dynamics of $\mathrm{Cd}, \mathrm{Cu}$ and $\mathrm{Pb}$ added to soil through different kinds of sewage sludge. Waste Management 28(5): 821-832.

50. Van der Merwe, G. M. E., M. C Laker and C. Buhmann. 2002. Clay mineral association in melanic soils of South Africa. Australian. Journal of Soil Research 40: 115-126.

51. Wei, B., F. Jiang, X. Li and S. Mu. 2010. Contamination levels assessment of potential toxic metals in road dust deposited in different types of urban environment Environ. Environmental Earth Sciences 61: 1187-1196.

52. Walna, B., W. Spychalski and A. Ibragimow. 2010. Fractionation of iron and manganese in the horizons of a nutrient-poor forest soil profile using the sequential extraction method. Polish Journal of Environmental Studies 19(5): 1029-1037.

53. Yadav, K. K. 2008. Micronutrient status in soils of udaipur district of rajasthan. Hydrology Journal 34: 3.

54. Yamamoto, M. and Y. Watanabe. 1996. The chemical forms of $\mathrm{Zn}, \mathrm{Mn}$ and $\mathrm{Cu}$ in soils of Sugadalra- Kuogen. Japanese. Soil Science and Plant Nutrition 67(3): 279-284.

55.Zhang, X. P., W. Deng and X. M. Yang. 2002. The background concentrations of 13 soil trace elements and their relationship to parent materials and vegetation in Xizang (Tibet). Journal of Asian Earth Sciences 21: 167-174.

56. Ziaeian, A. H. and M. J. Malakouti. 2001. Effects of Fe, Mn, Zn and $\mathrm{Cu}$ fertilization on the yield and grain quality of wheat in the calcareous soils of Iran. PP. 840-841. In: Horst W. J. et al. (Eds.), Plant Nutrition. Developments in Plant and Soil Sciences, Vol 92. Springer, Dordrecht. 


\title{
Effect of Climate and Soil Development on the Quantity and Chemical Forms Distribution of Iron, Copper, Zinc and Manganese Micronutrients in the Dominant Soil Orders of Kohgiluyeh and Boyerahmad Province
}

\author{
S. Shakeri ${ }^{1^{*}}$, A. Azadi ${ }^{2}$ and M. Saffari ${ }^{3}$
}

(Received: March 31-2020 ; Accepted: August 01-2020)

\begin{abstract}
Determining the relative distribution of each chemical form of the elements and their relationship with the physical, chemical, and clay mineralogical properties of soils can help researchers to achieve the sustainable agricultural management. The present study was conducted to evaluate the chemical forms of four micronutrients $(\mathrm{Zn}, \mathrm{Cu}, \mathrm{Fe}$ and $\mathrm{Mn}$ ) in some surface and subsurface soils of Kohgiluyeh and Boyer Ahmad province and their relationship with the physical, chemical and mineralogical properties of the soils. The results showed that the exchangeable and sorbed chemical forms of the studied elements were very low and negligible, but the residual, carbonate, and organic forms had the highest to lowest values of the chemical forms of these elements, respectively. Examination of the correlation of the chemical forms of these elements with soil properties showed the effective correlation of organic carbon values with the Zn chemical forms; also, there was a correlation between clay, silt, cation exchange capacity and calcium carbonate and the chemical forms of $\mathrm{Cu}, \mathrm{Fe}$ and $\mathrm{Mn}$. The correlation between the quantities of clay minerals and the chemical forms of these elements showed that the amounts of different forms of the studied elements were directly related to 2:1 clay silicate minerals (especially vermiculite). Evaluation of $\mathrm{Fe}$ and $\mathrm{Mn}$ chemical forms also showed that the amounts of these elements were higher in the soils with developed profiles (Alfisol and Mollisol), the wetter climate and zeric moisture regime rather than in soils with non-developed profiles (Entisols and Inceptisols) and a drier climate and a ustic moisture regime. In general, the results showed that variations of soil forming factors such as climate (as well as the total amount of each micronutrients), could be effective on the chemical forms of micronutrients (especially on Mn and $\mathrm{Fe}$ ); these can be effective in the management of weakly to highly-developed soils orders.
\end{abstract}

Keywords: Chemical forms, Micronutrients, Second clay minerals

1. Department of Agriculture, Payame Noor University, Tehran.

2. Soil and Water Research Department, Khuzestan Agricultural and Natural Resources Research and Education Center, AREEO, Ahvaz, Iran.

3. Department, Institute of Science and High Technology and Environmental Sciences, Graduate University of Advanced Technology, Kerman, Iran.

*: Corresponding Author, Email: Shakeri@pnu.ac.ir 